\title{
COMPUTO DE ALGUNOS PLAZOS EN EL CONCURSO DE ACREEDORES
}

\author{
Fernando Gómez Martín \\ Auditor y Censor Jurado de Cuentas \\ Profesor de Derecho concursal. Universidad de Deusto
}

Sumario: 1. Fase común. 1.1. Comunicación a acreedores. 1.2. Prohibición nombramiento administrador concursal. 1.3. Sanción por no aceptación del cargo. 1.4. Retribución. 1.5. Rendición de cuentas. 1.6. Continuación y acumulación juicios declarativos. 1.7. Interrupción de la prescripción. 1.8. Contratos de trabajo. 1.9. Rehabilitación de contratos. 1.10. Informe de la administración concursal. 1.10.1. Presentación del informe. 1.10.2. Formulación de cuentas anuales. 1.10.3. Comunicación de créditos. 1.10.4. Publicidad e impugnación del informe. 1.11. Propuesta de convenio anticipado (trámite escrito). 2. Fase de convenio. 2.1. Propuestas de convenio ordinario. 2.2. Junta de acreedores. 2.3. Presentación de propuestas de convenio. 2.4. Oposición al convenio aprobado. 2.5. Cumplimiento de convenio. 2.6. Incumplimiento de convenio. 2.7. Conclusión del concurso. 3. Fase de liquidación. 3.1. Plan de liquidación. 3.2. Informe. 4. Calificación del concurso. 4.1. Informe de la administración concursal. 4.2. Informe del Ministerio Fiscal. 5. Clausura y reapertura. 5.1. Clausura. 5.2. Reapertura. 6. Derecho transitorio concursal. 6.1. Conclusión y reapertura del procedimiento. 6.1.1. Conclusión. 6.1.2. Reapertura. 6.1.2.1. Inventario y lista de acreedores. 6.1.3. Apertura de concurso por incumplimiento de convenio. 6.1.4. Convenio en la quiebra. 6.1.5. Propuestas de convenio. 7. Suspensión de pagos. 8. Quiebra. Sección 1. ${ }^{a}$ Declaración de quiebra. Sección 2. ${ }^{a}$ Administración de la quiebra. Sección 3. ${ }^{a}$ Efectos de la retroacción de la quiebra. Sección 4. ${ }^{a}$ Examen, graduación y pago de los créditos contra la quebrada. Sección 5. ${ }^{a}$ Calificación de la quiebra y rehabilitación del quebrado. Sección 6. ${ }^{\mathrm{a}}$ Del convenio entre los acrreedores y el quebrado

Según la Exposición de Motivos: «X. La flexibilidad que inspira todo el procedimiento concursal se combina con las características de rapidez y simplicidad. La Ley de Enjuiciamiento Civil actúa como supletoria de la Ley Concursal, en cuanto ésta no contemple normas procesales especiales. La finalidad que se persigue es la de reconducir la complejidad del concurso a un procedimiento que permita su más pronta, eficaz y económica tramitación, sin merma de las garantías que exige la tutela judicial efectiva de todos los interesados». 
La Ley Concursal ${ }^{1}$ dedica la Disposición Final Quinta: «Derecho procesal supletorio. En lo no previsto en esta ley será de aplicación lo dispuesto en la Ley de Enjuiciamiento Civil, y específicamente en lo que se refiere al cómputo de todos los plazos determinados en la misma. En el ámbito de los procesos concursales, resultarán de aplicación los principios de la Ley de Enjuiciamiento Civil en cuanto a la ordenación formal y material del proceso».

Es la única mención de la Ley Concursal sobre cómputo de plazos, que he encontrado, por lo que habrá de acudirse a la Ley de Enjuiciamiento Civil, a saber: Arts. 130 a 136 de la vigente Ley de Enjuiciamiento Civil, que señala los términos para las actuaciones judiciales, particularmente el art. $133^{2}$ de la citada LEC, y coincide con los de general aplicación, establecidos en los arts. 182 a 185 de la Ley Orgánica del Poder Judicial, que concreta el citado art. 182: a) Son inhábiles a efectos procesales los sábados y domingos, los días 24 y 31 de diciembre, los días de fiesta nacional y los festivos a efectos laborales en la respectiva Comunidad Autónoma o localidad; b) Son inhábiles los días del mes de agosto; c) Los Jueces y Tribunales podrán habilitar los días y horas inhábiles, a instancia de parte, cuando hubiera causa urgente que lo exija, según dispone el art. 131 de la LEC; y, d) Los plazos procesales se computarán con arreglo a lo dispuesto en el Código Civil (art. $5^{3}$ ), aunque este artículo no resulta aplicable a los plazos procesales, sino a los plazos sustantivos civiles, tal y como tiene declarado la jurispru-

1 Ley 22/2003, de 9 de julio, Concursal, en vigor desde el uno de septiembre de dos mil cuatro.

2 «Cómputo de los plazos. 1. Los plazos comenzarán a correr desde el día siguiente a aquél en que se hubiere efectuado el acto de comunicación del que la Ley haga depender el inicio del plazo, y se contará en ellos el día del vencimiento, que expirará a las veinticuatro horas. No obstante, cuando la Ley señale un plazo que comience a correr desde la finalización de otro, aquél se computará, sin necesidad de nueva notificación, desde el día siguiente al del vencimiento de éste. 2. En el cómputo de los plazos señalados por días se excluirán los inhábiles. Para los plazos que se hubiesen señalado en las actuaciones urgentes a que se refiere el apartado 2 del artículo 131 no se considerarán inhábiles los días del mes de agosto y sólo se excluirán del cómputo los domingos y festivos. 3. Los plazos señalados por meses o por años se computarán de fecha a fecha. Cuando en el mes del vencimiento no hubiera día equivalente al inicial del cómputo, se entenderá que el plazo expira el último del mes. 4. Los plazos que concluyan en domingo u otro día inhábil se entenderán prorrogados hasta el siguiente hábil».

3 «1. Siempre que no se establezca otra cosa, en los plazos señalados por días, a contar de uno determinado, quedará éste excluido del cómputo, el cual deberá empezar en el día siguiente; y si los plazos estuviesen fijados por meses o años, se computarán de fecha a fecha. Cuando en el mes del vencimiento no hubiera día equivalente al inicial del cómputo, se entenderá que el plazo expira el último del mes. 2. En el cómputo civil de los plazos no se excluyen los días inhábiles». 
dencia, por todas, la STS de 28 de septiembre de 2000, y en los señalados por días quedarán excluidos los inhábiles.

Interesa, en particular, la norma sobre presentación de escritos, por los interesados, especialmente por la administración concursal, sujetos a plazo, que constituye una trascendental novedad, que podrá efectuarse hasta las quince horas del día hábil siguiente al del vencimiento del plazo, en la Secretaría del Tribunal o, de existir, en la oficina o servicio central que se haya establecido (art. 135.1 LEC).

Respetuoso con lo dispuesto en los arts. 184.2 de la LOPJ y 131.1 de la LEC, el art. 187 de la Ley Concursal previene: «Extensión de facultades del juez del concurso. 1. El juez podrá habilitar los días y horas necesarios para la práctica de las diligencias que considere urgentes en beneficio del concurso».

En relación con el citado art. 133 de la LEC, interesa el auto del Juzgado de lo Mercantil n. ${ }^{\circ} 1$ de Cádiz, de tres de mayo de dos mil cinco, «FUNDAMENTOS DE DERECHO. PRIMERO.-Con carácter previo, han de hacerse algunas consideraciones respecto del plazo de presentación del recurso, que el concursado califica de extemporáneo. Como se indicara en la providencia de 11 de abril de 2005, el recurso ha sido interpuesto dentro de plazo, ya que el mismo ha de computarse conforme al art. 133 LEC, es decir, excluyendo los días inhábiles, comenzando a contar desde el día siguiente al acto de comunicación, y contando el día del vencimiento, que expirará a las veinticuatro horas, es decir, en el presente caso, el plazo vencía el 11 de abril, fecha de presentación del recurso».

Por su especialidad, merece atención el art. 191 de la Ley Concursal: «1. Con carácter general, acordado el procedimiento abreviado, los plazos previstos en esta ley se reducirán a la mitad, redondeada al alza si no es un número entero, salvo aquéllos que, por razones especiales, el juez acuerde mantener para el mejor desarrollo del procedimiento. En todo caso, el plazo para la presentación del informe por la administración concursal será de un mes a contar desde la aceptación del cargo y sólo podrá autorizarse una prórroga por el juez del concurso no superior a quince días».

De acuerdo con lo expuesto, en el procedimiento concursal, los plazos se computan contando exclusivamente los días hábiles, salvo en el caso previsto en el art. 64.5: «Recibida la solicitud, el juez convocará a los representantes de los trabajadores y a la administración concursal a un período de consultas, cuya duración no será superior a treinta días naturales, o a quince, también naturales, en el supuesto de empresas que cuenten con menos de cincuenta trabajadores».

Según la STC 64/2005, de 14 de marzo de 2005: Fundamentos jurídicos. 3... «es doctrina constitucional consolidada que "la fijación de 
un plazo para la evacuación de un trámite procesal representa, contemplado desde la perspectiva de la parte a la que le corresponde su cumplimiento, tanto la imposición de una carga de actuar tempestivamente como el reconocimiento del derecho a disponer del plazo en su totalidad" (SSTC 269/2000, de 30 de octubre, FJ 5; 38/2001, de 12 de febrero, FJ 2; 54/2001, de 26 de febrero, FJ 2; y 222/2003, de 15 de diciembre, FJ 4)».

Sobre términos y plazos, resulta de interés el auto del Tribunal Superior de Justicia de Cataluña, de 22.09.1994, que cita abundante jurisprudencia e incide en el carácter preclusivo de los plazos procesales en aras de garantizar la seguridad jurídica.

Trataré de repasar los principales plazos procesales que afectan a la administración concursal, en las sucesivas fases del concurso.

\section{Fase común}

La declaración de concurso voluntario o necesario se hará por auto judicial, según el art. 21 de la Ley Concursal: «1. El auto de declaración de concurso contendrá los siguientes pronunciamientos:... 2. El auto producirá sus efectos de inmediato, abrirá la fase común de tramitación del concurso, que comprenderá las actuaciones previstas en los cuatro primeros títulos de esta Ley, y será ejecutivo aunque no sea firme».

\subsection{Comunicación a acreedores}

Art. 21.4: "La administración concursal realizará sin demora una comunicación individualizada a cada uno de los acreedores cuya identidad y domicilio consten en el concurso, informándoles de la declaración de éste y del deber de comunicar sus créditos, en la forma establecida en el artículo 85» [Por escrito, ante el juzgado y en el plazo estipulado en el art. 21.1.5. : «El llamamiento a los acreedores para que pongan en conocimiento de la administración concursal la existencia de sus créditos, en el plazo de un mes a contar desde la última de las publicaciones acordadas en el auto, dentro de las que con carácter obligatorio establece el apartado 1 del artículo 23»].

Sin demora significa que la administración concursal realizará la preceptiva comunicación sin tardanza o dilación, pero ¿a partir de cuándo? Considero que a partir de la aceptación del segundo de los administradores concursales, por analogía con lo establecido en el art. 74 de la Ley Concursal: «El plazo para la presentación del informe de los administradores concursales será de dos meses, contados a partir 
de la fecha en que se produzca la aceptación de dos de ellos», es decir, desde el día siguiente.

\subsection{Prohibición nombramiento administrador concursal}

Según el apartado 1 del art. 28: «No podrán ser nombrados administradores concursales... quienes hayan prestado cualquier clase de servicios profesionales al deudor o a personas especialmente relacionadas con éste en los últimos tres años, incluidos aquéllos que durante ese plazo hubieran compartido con aquél el ejercicio de actividades profesionales de la misma o diferente naturaleza...». Parece que el referido plazo de los tres últimos años se computará desde la fecha del auto de declaración de concurso.

Según el apartado 2 del referido art. 28, obstativa para los profesionales (abogados, auditores de cuentas, economistas o titulados mercantiles colegiados), no podrán ser nombrados administradores concursales por el mismo juzgado si hubieren sido designados en tres concursos dentro de los dos años anteriores. De igual modo, considero que el mencionado plazo de dos años se computará a partir del auto de declaración del concurso en el que se acuerde el cuarto nombramiento.

\subsection{Sanción por no aceptación del cargo}

El apartado $1 \mathrm{del}$ art. 29 impone el deber de comparecencia judicial al administrador designado, fuese profesional o acreedor, y le faculta para aceptar o no el nombramiento, pero si no compareciese o no aceptase, sin justa causa, según el apartado 2, sufrirá la sanción de no ser designado administrador concursal en los procedimientos que puedan seguirse en el partido judicial, durante un plazo de tres años. El citado plazo de tres años se computará, según creo, a partir del día siguiente de la fecha de notificación del auto en que hubiese sido designado y no comparecido o aceptado el cargo.

\subsection{Retribución}

Según el apartado 3 del art. 34, el juez, previo informe de la administración concursal, fijará por medio de auto y conforme al arancel la cuantía de la retribución, así como los plazos en que deba ser satisfecha. El señalamiento de estos plazos de pago de la retribución a los administradores concursales tiene efectos en la concurrencia de créditos contra la masa (art. 84.2), sobre el pago de estos créditos prededucibles, según el 
art. 154.34: «En caso de resultar insuficientes, lo obtenido se distribuirá entre todos los acreedores de la masa por el orden de sus vencimientos». La norma reglamentaria, que aprueba el citado arancel, por Real Decreto $1.860 / 2004$, de 6 de septiembre, dispone en el art. 8: «Plazos para la percepción de la retribución. Salvo que el juez del concurso establezca otros plazos, la retribución de los administradores concursales correspondiente a la fase común se abonará de la siguiente forma: a) El 50 por ciento de la retribución se abonará dentro de los cinco días siguientes al de la firmeza del auto que la fije; b) El 50 por ciento restante se abonará dentro de los cinco días siguientes al de la firmeza de la resolución que ponga fin a la fase común». De nuevo el dies a quo, a partir del cual podrá percibir la administración concursal, será a partir de que reciban la notificación de la resolución correspondiente.

\subsection{Rendición de cuentas}

El administrador concursal cesado deberá rendir cuentas de su actuación, en las competencias que le hubieran sido atribuidas, según el art. 38.4: "En caso de cesar cualquiera de los administradores concursales antes de la conclusión del concurso, el juez le ordenará rendir cuentas de su actuación en las competencias que le hubieran sido atribuidas individualmente, en su caso. Cuando el cese afecte a todos los miembros de la administración concursal, el juez ordenará a ésta que rinda cuentas de su entera actuación colegiada hasta ese momento, sin perjuicio de la responsabilidad que corresponda a cada uno de los administradores conforme a las reglas del artículo 36. Estas rendiciones de cuentas se presentarán por los citados administradores dentro del plazo de un mes, contado desde que les sea notificada la orden judicial, y serán objeto de los mismos trámites, resoluciones y efectos previstos en el artículo 181 para las rendiciones de cuentas a la conclusión del concurso». Queda claro, por tanto, que el administrador concursal o el órgano colegiado cesado tienen un plazo de un mes para rendir cuentas, desde que reciba la notificación judicial, mes hábil y no computable el mes de agosto.

\subsection{Continuación y acumulación juicios declarativos}

Artículo 51. «1. Los juicios declarativos en que el deudor sea parte y que se encuentren en tramitación al momento de la declaración de concurso se continuarán hasta la firmeza de la sentencia. No obstante,

${ }_{4}$ Nueva inclusión en el referido informe de la Ponencia del Congreso de los Diputados. 
se acumularán aquéllos que, siendo competencia del juez del concurso, según lo previsto en el artículo 8, se estén tramitando en primera instancia y respecto de los que el juez del concurso estime que su resolución tiene trascendencia sustancial para la formación del inventario o de la lista de acreedores. La acumulación podrá solicitarse por la administración concursal, antes de emitir su informe, o por cualquier parte personada, antes de la finalización del plazo de impugnación del inventario y de la lista de acreedores». Se observa un plazo, para que la administración concursal pueda solicitar la acumulación de juicios declarativos en los que el concursado sea parte, que se computará con relación a otro, vinculado al previsto para la presentación de su informe, que el art. 74 de la Ley Concursal señala en dos meses, prorrogable por un mes más. Respecto de la acumulación solicitada por cualquier parte personada, también se remite a otro plazo estipulado en el art. 96 de la Ley Concursal: «Impugnación del inventario y de la lista de acreedores. 1. Dentro del plazo de diez días a contar desde la comunicación a que se refiere el apartado 2 del artículo anterior, cualquier interesado podrá impugnar el inventario y la lista de acreedores, a cuyo fin podrá obtener copia a su costa». El mencionado apartado 2 del art. 95 dispone: «La presentación al juez del informe de la administración concursal y de la documentación complementaria se comunicará de acuerdo con lo dispuesto en el artículo $23^{5}$ y se publicará en el tablón de anuncios del juzgado», es decir, tendrá lugar la denominada publicidad noticia.

«2. En caso de suspensión de las facultades de administración y disposición del deudor, la administración concursal, en el ámbito de sus competencias, sustituirá a éste en los procedimientos judiciales en trámite, a cuyo efecto se le concederá, una vez personada, un plazo de cinco días para que se instruya en las actuaciones...». Cuando el deudor haya sido suspendido en sus facultades de administración y disposición patrimoniales, de acuerdo con lo previsto en el art. 40, la administración concursal le sustituirá en los procedimientos judiciales en

5 «1. La publicidad de la declaración de concurso, así como de las restantes notificaciones, comunicaciones y trámites del procedimiento, podrá realizarse por medios telemáticos, informáticos y electrónicos, en la forma que reglamentariamente se determine, garantizando la seguridad y la integridad de las comunicaciones. No obstante lo anterior, la declaración del concurso se anunciará en el "Boletín Oficial del Estado" y en un diario de los de mayor difusión en la provincia donde el deudor tenga el centro de sus principales intereses, así como en uno de los de mayor difusión en la provincia donde radique su domicilio. Estos anuncios contendrán los datos suficientes para identificar el proceso y las formas de personarse en él. La publicación en el "Boletín Oficial del Estado" y, en su caso, en otros periódicos oficiales del edicto se insertará con la mayor urgencia». 
trámite y dispondrá de un plazo de cinco días para instruirse en las actuaciones, a partir de su personamiento, por supuesto, días hábiles.

\subsection{Interrupción de la prescripción}

Queda interrumpida la prescripción de acciones contra el deudor, así como contra socios y contra administradores, liquidadores y auditores de la persona jurídica deudora, por créditos concursales, desde la declaración hasta la conclusión del concurso (art. 60). Al instituto de la prescripción dedica el Código Civil los arts. 1.930 a 1.975, particularmente, a la prescripción de acciones, a partir del art. 1.961; la Ley General Tributaria los arts. 66 a 70 y la Ley General de la Seguridad Social el art. 21 (cuatro años). Sobre responsabilidades de socios, administradores, liquidadores y auditores de la persona jurídica, el TRLSA dedica los arts. 15, 18, 30 a 33, 39, 46, 133 a 135, 211, 230, 232, 236 y 279. Clausurado el concurso, comienza de nuevo el cómputo de los plazos de prescripción.

\subsection{Contratos de trabajo}

Art. 64: «3. La adopción de las medidas previstas en el apartado anterior [modificación sustancial de las condiciones de trabajo y la extinción o suspensión colectivas de los contratos de trabajo en que sea empleador el concursado] sólo podrá solicitarse del Juez del concurso una vez emitido por la administración concursal el informe a que se refiere el capítulo I del título IV de esta Ley, salvo que se estime que la demora en la aplicación de las medidas colectivas pretendidas puede comprometer gravemente la viabilidad futura de la empresa, en cuyo caso, y con acreditación de esta circunstancia, podrá realizarse la petición al juez en cualquier momento procesal desde la presentación de la solicitud de declaración de concurso». Ya hemos recordado que la administración debe rendir su informe ex art. 75, en el plazo de dos meses, prorrogable por un mes más (un mes, prorrogable por quince días, en procedimiento abreviado).

«5. Recibida la solicitud, el juez convocará a los representantes de los trabajadores y a la administración concursal a un período de consultas, cuya duración no será superior a treinta días naturales, o a quince, también naturales, en el supuesto de empresas que cuenten con menos de cincuenta trabajadores». Unica referencia a cómputo de días hábiles en la Ley Concursal.

«6... Al finalizar el plazo señalado o en el momento en que se consiga un acuerdo, la administración concursal y los representantes de 
los trabajadores comunicarán al juez del concurso el resultado del período de consultas. Recibida dicha comunicación el juez del concurso recabará un informe de la Autoridad Laboral sobre las medidas propuestas o el acuerdo alcanzado, que deberá ser emitido en el plazo de quince días, pudiendo ésta oír a la administración concursal y a los representantes de los trabajadores antes de su emisión. Recibido el informe por el juez del concurso o transcurrido el plazo de emisión, seguirá el curso de las actuaciones. Si el informe es emitido fuera de plazo, podrá no obstante ser tenido en cuenta por el juez del concurso al adoptar la correspondiente resolución». Plazo computable en días hábiles.

«9. En el supuesto de acordarse una modificación sustancial de carácter colectivo de las previstas en el artículo 41 del Estatuto de los Trabajadores, el derecho de rescisión de contrato con indemnización, que para tal supuesto reconoce dicha norma legal, quedará en suspenso durante la tramitación del concurso y con el límite máximo de un año desde que se hubiere dictado el auto judicial que autorizó dicha modificación...Tanto en este caso como en los demás supuestos de modificación sustancial de las condiciones de trabajo, la improcedencia del ejercicio de la acción de rescisión derivada de la modificación colectiva de las condiciones de trabajo no podrá prolongarse por un período superior a doce meses, a contar desde la fecha en que se hubiere dictado el auto judicial que autorizó dicha modificación». El cómputo de estos doce meses será excluido agosto.

Art. 65: «Contratos del personal de alta dirección. 1. Durante la tramitación del concurso, la administración concursal, por propia iniciativa o a instancia del deudor, podrá extinguir o suspender los contratos de éste con el personal de alta dirección. 2. En caso de suspensión del contrato, éste podrá extinguirse por voluntad del alto directivo, con preaviso de un mes, conservando el derecho a la indemnización en los términos del apartado siguiente» [el juez del concurso podrá moderar la indemnización que corresponda al alto directivo]. También en el cómputo del plazo de un mes será excluido agosto.

\subsection{Rehabilitación de contratos}

Posible rehabilitación de créditos por préstamo, así como de los contratos de adquisición de bienes muebles o inmuebles con contraprestación o precio aplazado, cuyo vencimiento anticipado o resolución, respectivamente, se haya producido dentro de los tres meses antes de la declaración de concurso (arts. 68 y 69). Para el cómputo de este plazo, se excluirá agosto. 
1.10. Informe de la administración concursal

En el Título IV de la Ley Concursal, dedicado al informe de la administración concursal y a la determinación de la masa activa y pasiva del concurso, se establecen algunos plazos que han sido objeto de debate.

\subsubsection{PResentación DEL INFORME}

El art. 74 dispone: «1. El plazo para la presentación del informe de los administradores concursales será de dos meses, contados a partir de la fecha en que se produzca la aceptación de dos de ellos. 2. Este plazo podrá ser prorrogado por el juez, por tiempo no superior a un mes, a solicitud de la administración concursal, presentada antes de su expiración y fundada en circunstancias extraordinarias...». De igual modo, en el cómputo de este plazo se excluye agosto.

Conviene recordar que, en procedimiento abreviado (arts. 190 y 191), el plazo establecido será de un mes, que podrá prorrogarse no más de quince días. Es decir, un mes hábil, no agosto, y quince días hábiles.

Breves plazos, en cualquier caso, particularmente si se considera que comienzan a contar desde la fecha de aceptación de dos de los tres administradores concursales (art. 27) o del administrador concursal único (art. 191.2), cuando los acreedores disponen del plazo de un mes para comunicar a la administrador concursal, a través del Juzgado, la existencia de sus créditos, según el art. 85, que se remite al art. 21.1.5. ${ }^{\circ}$ : «El llamamiento a los acreedores para que pongan en conocimiento de la administración concursal la existencia de sus créditos, en el plazo de un mes a contar desde la última de las publicaciones acordadas en el auto, dentro de las que con carácter obligatorio establece el apartado 1 del artículo 23». Es decir, los acreedores pueden disponer de plazo superior, para comunicar sus créditos, al que tenga la administración concursal para presentar su informe, circunstancia extraordinaria, entre otras, que permitirá la prórroga prevista.

Sin embargo, se ha arbitrado una solución por el Juzgado de lo Mercantil n. ${ }^{\circ} 1$ de Bilbao, en auto de fecha 29.04.2005: «FUNDAMENTOS DE DERECHO. SEXTO.—Los arts. 74 y 191 de la LC establecen que los plazos para la emisión del informe por los administradores concursales se computarán desde la aceptación bien de dos de ellos, en el caso del concurso ordinario, bien el único, en el caso del abreviado. El art. 75.2 de la LC obliga a acompañar al informe de la administración concursal un listado de acreedores.

Estos se determinan a través de la comunicación de créditos a la que alude el art. 21.1.5 de la LC, que, como expresa tal precepto, pue- 
de realizar en el término de un mes desde la última de las publicaciones que hay que verificar.

Sin embargo la experiencia ha constatado que dichas publicaciones, sobre todo en periódicos oficiales, se demoran incluso un mes, por lo que pese a las prórrogas que es posible conceder a los administradores, resulta que hay acreedores que comunican sus créditos dentro del plazo legal pero después de que los administradores hayan evacuado el informe.

El perjuicio que se causa a los acreedores es evidente. Si la comunicación se produce después del término para elaborar el informe, aunque sea dentro del plazo que concede esta resolución conforme a lo dispuesto en la ley, es decir, dentro del mes siguiente a la última publicación, el crédito se calificará como subordinado al haberse comunicado tardíamente (art.92.1 LC).

Con ello se obliga al acreedor, que no ha incurrido en gasto para insinuar su crédito por la previsión del art. 184.3 de la Ley Concursal, a plantear un incidente concursal para el que, conforme a ese precepto y al art. 96.4 de la misma norma, precisa de abogado y procurador.

El acreedor se ve perjudicado por el gasto en el que tiene que incurrir, la administración concursal padece la inseguridad de la superposición de los plazos, el procedimiento se dilata por el planteamiento de incidentes concursales superfluos, ya que los créditos se comunican en plazo, todo por el retraso de la publicación de los edictos anunciadores del concurso, que no es imputable a quien lo promueve.

La previsión legal, en consecuencia, debe ser matizada ante la realidad de la escasa celeridad de algunos organismos en la publicación de los anuncios. Por ello se considera prudente y razonable que el término para la emisión del informe por parte de la administración concursal, se inicie desde la última de las publicaciones, y no desde la aceptación de dos de ellos o del único en el caso del procedimiento abreviado, lo que se hará constar en la parte dispositiva de esta resolución».

\subsubsection{Formulación DE CUENTAS ANUALES}

El art. 75, sobre contenido del referido informe, dispone: $« 1.2{ }^{\circ} \ldots$ Si el deudor no hubiese presentado las cuentas anuales correspondientes al ejercicio anterior a la declaración de concurso, serán formuladas por la administración concursal, con los datos que pueda obtener de los libros y documentos del deudor, de la información que éste le facilite y de cuanta otra obtenga en un plazo no superior a quince días». En Anteproyecto de la Comisión General de Codificación y el Proyecto 
de Ley Concursal (BOCG 23.07.2002), señalaban: «Si el deudor no hubiese presentado las cuentas anuales correspondientes al ejercicio anterior a la declaración de concurso, serán formuladas por la administración judicial, con los datos que pueda obtener de los libros y documentos del deudor, de la información que éste le facilite y de cuanta otra obtenga. En este caso, la documentación contable elaborada será sometida a verificación por un auditor de cuentas designado por el Juez, cuyo informe se unirá al de la administración judicial. Esta misma verificación también procederá cuando las cuentas anuales correspondientes al último ejercicio...». La modificación del texto anterior se plasma en el informe de la Ponencia de la Comisión del Congreso, sin que enmienda alguna mencionase el plazo no superior a quince días para la formulación de las cuentas anuales por la administración concursal.

Considero que puede interpretarse este plazo de quince días como complementario del que disponen los administradores concursales para rendir su informe, es decir, de los dos meses concedidos en el art. 74, aunque también escaso para formular las cuentas anuales, que requiere actualizar los registros contables a la fecha de cierre del ejercicio inmediato anterior, en su caso, llevar a cabo el corte de operaciones, efectuar inventarios y practicar la regularización contable. La verdad es que este precepto suscita algunas dudas, pues también puede interpretarse que el plazo de quince días corre desde la aceptación del segundo administrador concursal, si se pone en relación con lo establecido en el art. 75.1.

\subsubsection{COMUNICACIÓN DE CRÉDITOS}

El apartado 1 del art. 85 es concordante con lo dispuesto en el art. 21.1, que expresamente cita: «El auto de declaración de concurso contendrá los siguientes pronunciamientos:... 5. ${ }^{o}$ El llamamiento a los acreedores para que pongan en conocimiento de la administración concursal la existencia de sus créditos, en el plazo de un mes a contar desde la última de las publicaciones acordadas en el auto, dentro de las que con carácter obligatorio establece el apartado 1 del artículo 23», y con el art. 21.4: «La administración concursal realizará sin demora una comunicación individualizada a cada uno de los acreedores cuya identidad y domicilio consten en el concurso, informándoles de la declaración de éste y del deber de comunicar sus créditos, en la forma establecida en el artículo 85». Recuerdo la obligación de información a los acreedores conocidos que tengan su residencia habitual, su domicilio o su sede en los demás Estados miembros de la Unión Europea, se- 
gún el mencionado art. 40 del Reglamento Comunitario, de obligado cumplimiento desde el 31.05.2002, aunque en la práctica concursal anterior se ha desconocido, en general, así como lo dispuesto en el art. 214 de la Ley Concursal, que impone el deber a la administración concursal de informar sin demora a los acreedores conocidos, que tengan su residencia habitual, domicilio o sede en el extranjero, de que ha sido declarado en concurso su deudor. Llamo la atención en que el plazo para insinuar sus créditos por estos acreedores «extranjeros» (un mes, también hábil) se computará desde la fecha en que reciban la nota o escrito de la administración concursal. Conviene recordar que en procedimiento abreviado el plazo establecido será de quince días (arts. 190 y 191).

Sobre cómputo de este plazo de comunicación de créditos por los acreedores, al Juzgado, se pronuncia la Sentencia del Juzgado de lo Mercantil número uno de La Coruña, de fecha siete de septiembre de dos mil cinco: «FUNDAMENTOS DE DERECHO. PRIMERO.-Sobre el cómputo del plazo de un mes que establece el artículo 85.1 de la Ley Concursal, por remisión al artículo 21.1 5. , la propia Ley establece que se contará desde la última de las publicaciones acordadas en el auto de declaración de concurso. La jurisprudencia del Tribunal Supremo a propósito del antiguo artículo 304 de la LEC de 1881, análogo al actual artículo 133 de la LEC 1/2000, resalta la especialidad de la regla relativa al cómputo de los plazos señalados por meses o años, que se computarán de fecha a fecha, de modo que aunque el plazo comience a correr desde el día siguiente a aquél en que se hubiere efectuado el acto de comunicación del que la Ley haga depender el inicio del plazo (artículo 133. 1) el plazo vence el mismo día del mes correspondiente a aquél en que se hizo la notificación o publicación. En este caso, si la publicación del último de los edictos es de fecha 25 de abril de 2005, el plazo de un mes para la insinuación de los créditos vencía el 25 de mayo siguiente, aunque a efectos de la presentación de escritos sea de aplicación lo dispuesto en el artículo 135.1 de la LEC con lo que los acreedores podrían haber presentado en el Juzgado - en la oficina de recepción de escritos del Decanato-sus títulos de crédito hasta las quince horas del día 26 de mayo (jueves)».

El reconocimiento de créditos o su exclusión de la masa pasiva corresponden a la administración concursal y se materializa en la lista de acreedores, según dispone el primer inciso del párrafo primero del apartado 1, del artículo 86, que debe acompañar a su informe ex art. 75.2.2. , y comprenderá una relación de los incluidos y otra de los excluidos, ordenadas alfabéticamente (artículo 94.1). La decisión de inclusión o exclusión de créditos se adoptará respecto de cada uno de ellos, y se referirá tanto a los comunicados por sus titulares como los que resultaran 
de los libros y documentos del deudor o por cualquier otra razón constaran en el concurso, según previene el inciso final del párrafo primero del citado apartado 1 del art. 86. Es decir, que la administración concursal, aunque el acreedor no hubiese comunicado su crédito, ni acompañado el título o documentos de su crédito (art. 85) o lo hubiese hecho fuera del plazo establecido en el art. 21.1.5. ${ }^{\circ}$, podrá incluirlo en la lista de acreedores, si alcanza evidencia suficiente sobre el mismo, de la verificación de los antecedentes del deudor (libros y documentos) o por cualquier otra razón constaren en el concurso. Las cuestiones que se susciten sobre tales créditos se tramitarán como incidente concursal, como establece el párrafo segundo del mencionado art. 86.1, regulado en los arts. 192 a 196.

Y ¿cual será la clasificación de estos créditos incluidos en la lista de acreedores de la administración concursal? La que corresponda a su naturaleza, según los arts. 90 a 92. Este último precepto dispone: «Son créditos subordinados: $10^{\circ}$ Los créditos que, habiendo sido comunicados tardíamente, sean incluidos por la administración concursal en la lista de acreedores o que, no habiendo sido comunicados oportunamente, sean incluidos en dicha lista por el Juez al resolver sobre la impugnación de ésta, salvo que se trate de créditos cuya existencia resultare de la documentación del deudor, constaren de otro modo en el concurso o en otro procedimiento judicial, o que para su determinación sea precisa la actuación inspectora de las Administraciones Públicas, teniendo en todos estos casos el carácter que les corresponda según su naturaleza...». Es decir, si se dan estos requisitos, «que se trate de créditos cuya existencia resultare de la documentación del deudor, constaren de otro modo en el concurso o en otro procedimiento judicial, o que para su determinación sea precisa la actuación inspectora de las Administraciones Públicas», tendrán el carácter que les corresponda según su naturaleza, sin que influya en su clasificación el hecho de haber sido comunicados tardíamente o no haber sido comunicados.

El incumplimiento por los acreedores del deber de comunicación de créditos, cuando no sean incluidos por la administración concursal en la lista de acreedores y los reconozca el juez al resolver sobre la impugnación del informe, así como los incluidos por la administración concursal en dicha lista, pero comunicados tardíamente, serán clasificados como créditos subordinados, salvo que se trate de créditos cuya existencia resultase de la documentación del deudor, constare de otro modo en el concurso o en otro procedimiento judicial, o que para su determinación sea preciso la actuación inspectora de las Administraciones Públicas (art. 92.1. ${ }^{\circ}$ ). 
Así se deduce de la Sentencia del Juzgado de lo Mercantil número uno de La Coruña, de fecha siete de septiembre de dos mil cinco: «FUNDAMENTOS DE DERECHO. SEGUNDO.-Cuestión distinta es la referente a la aplicación que la administración concursal ha hecho de la regla de postergación de créditos comunicados tardíamente que establece el artículo 92.1 de la Ley Concursal, sin tener en cuenta que la clasificación de un crédito comunicado fuera de plazo como subordinado tiene como excepción, entre otras, el supuesto de que se trate de créditos que resulten de la documentación del deudor o que constaren de otro modo en el concurso. Y así, en la relación aportada con la solicitud inicial de la concursada figura la TGSS como acreedora por $111.787,26 €$, de modo que el crédito por ese importe ya constaba en el concurso y, con toda seguridad, también en la documentación del deudor. La postergación del crédito de la Tesorería por ese importe, desde el momento en que consta en el concurso, no puede ya sustentarse en el artículo 92. 1 de la LC sino, en su caso, en la ubicación concreta del crédito o de partes del mismo en alguna de las demás hipótesis del mismo artículo $92 \ldots$

TERCERO.-Así pues, la demanda debe ser parcialmente estimada en el sentido de limitar la postergación correspondiente a créditos comunicados fuera de plazo a los 32.727,33 € de diferencia que no constaban en el concurso. Los 111.787,26 € restantes, ya inicialmente reconocidos por el deudor, deben ser clasificados según su naturaleza y esta clasificación corresponde hacerla a la administración concursal en su informe definitivo (artículo 96. 4 de la LC) siguiendo las premisas siguientes: Se considerará que la comunicación fuera de plazo afecta a los créditos correspondientes a las últimas liquidaciones, según criterio temporal, de las incluidas en la "relación de deudas" de la certificación de la TGSS. Si para obtener la cifra exacta de 111.787,26 € fuera necesario escindir parte de la deuda consignada en alguno de los documentos de la referida relación, se tomará en primer lugar de la correspondiente al recargo. La administración concursal clasificará el crédito así obtenido por importe de 111.787,26 € siguiendo los mismos criterios de la certificación de la TGSS y sus anexos. Puesto que no se ha suscitado debate alguno al respecto entre las partes ni se ha sometido en consecuencia esta cuestión a la decisión del juzgado, no es posible —en obediencia al principio de justicia rogada-imponer en este caso un criterio diferente de clasificación - en lo referente a recargos y al alcance del privilegio del artículo 91. 4 de la LC-como el que se ha ordenado seguir en sentencias incidentales que resolvieron esta cuestión en otros concursos de este mismo Juzgado». 
No obstante, la casuística presenta otras situaciones de hecho que resuelve la Sentencia del Juzgado de lo Mercantil Núm. 1 de Madrid, de fecha veinticinco de mayo de dos mil cinco: «FUNDAMENTOS JURIDICOS. SEGUNDO.-Decididas las cuestiones previas, se nos permite entrar en el fondo de la cuestión planteada por la entidad Zahonero, S.L. Esta, mediante la demanda incidental, pretende verse incluida en la lista de acreedores por la cuantía de 809,31 euros y como titular de un crédito ordinario. En el plano de los hechos la cuestión es pacífica. Zahonero, S.L. admite que no ha comunicado su crédito de ninguna manera. Sin embargo, entiende -y así lo expresa en el primer párrafo del hecho segundo de su demanda-que se encuentra dentro de plazo para ello. Debemos partir de la siguiente premisa: el incidente concursal de impugnación de la lista de acreedores no es una vía válida para la insinuación de un crédito. Los apartados 2 y 3 del artículo 85 LC exigen que se lleve a cabo la comunicación de créditos mediante escrito firmado por el acreedor, por cualquier otro interesado en el crédito o por quien acredite representación suficiente de ellos, debiéndose presentar en el Juzgado; además el escrito deberá expresar nombre, domicilio y demás datos de identidad del acreedor, así como los relativos al crédito, su concepto, cuantía, fechas de adquisición y vencimiento, y características y calificación que se pretenda. Ni se hizo esta comunicación, ni consta que de cualquier otra forma la Administración concursal pudiera tener conocimiento del crédito pretendido por Zahonero, S.L.

TERCERO.-Dadas las circunstancias de hecho, la cuestión que se suscita es la de los efectos de la falta de insinuación tempestiva en el concurso. Esta cuestión fue resuelta por este Juzgado mediante Auto de fecha 10 de marzo de 2005 en los autos de concurso voluntario núm. 18/04 en el sentido de no atribuir a las comunicaciones extemporáneas, esto es, fuera del término que el artículo 74.1 LC concede a la Administración concursal para la presentación del informe, ninguna eficacia en el ámbito del concurso. $Y$ debe considerarse comunicación extemporánea la que se lleva a cabo mediante la demanda de impugnación de la lista de acreedores. La conclusión a la que acabamos de aludir, debe ser aquí mantenida. Para ello debemos partir de los plazos que la Ley Concursal marca para la Administración concursal a fin de que confeccione el informe y los documentos que han de serle unidos, en especial, la lista de acreedores (artículo 75.2.2. ${ }^{\circ}$ LC). El artículo 74.1 de la Ley 22/2003, de 9 de julio, Concursal (en adelante LC), impone a la administración concursal el deber de presentar el informe en el plazo de dos meses - prorrogable por otro si concurren, y se justifican, circunstancias extraordinarias (artículo 74.2 LC) - a contar desde la aceptación del 
cargo de al menos dos de sus miembros. El otro plazo que debe ser tenido en cuenta para resolver la cuestión que se suscita es el que la Ley concede a los acreedores para que insinúen su crédito en el concurso. A tal efecto, el artículo 21.1.5. ${ }^{\circ}$ LC concede a los acreedores del concursado el plazo de un mes a contar desde la última de las publicaciones obligatorias acordadas en el Auto de declaración del concurso. En el supuesto, que es el que debemos considerar, en el que el término para la comunicación de créditos expire con anterioridad al que corresponde a la Administración concursal para la presentación de su informe, podemos contemplar tres hipótesis distintas que derivan de la combinación de los dos plazos a los que acabamos de aludir más arriba. La primera, consistente en que el acreedor del concursado comunique su crédito dentro del plazo del mes previsto en el artículo 21.1.5. ${ }^{\circ} \mathrm{LC}$. La segunda, que el acreedor comunique su crédito una vez transcurrido el plazo del mes previsto en el artículo 21.1.5. ${ }^{\circ} \mathrm{LC}$, pero con anterioridad a la expiración del plazo que la administración tiene para la entrega del informe. La tercera, que el acreedor comunique su crédito transcurrido el plazo que ésta tiene para la presentación de su informe.

CUARTO.-En la primera hipótesis, que debería constituirse en la ordinaria, la consecuencia es que la Administración concursal deberá proceder a examinar la solicitud y la documentación presentada por el acreedor, y la valorará según las normas para la determinación de la masa pasiva acordando la procedencia o improcedencia de su inclusión en la lista de acreedores y, en su caso, con la calificación que corresponda (artículo 86.1 LC). En la segunda hipótesis, nos encontramos ante lo que la Ley califica como de comunicación tardía de créditos. Las consecuencias que el artículo 92.1 LC anuda a la comunicación tardía de créditos pone de relieve la importancia para el acreedor de comunicar su crédito dentro del plazo que la Ley le concede. Aquí hay que hacer un inciso. No nos encontramos contemplando los supuestos en los que los créditos derivan de los libros y documentos del deudor o por cualquier otra razón consten en el concurso. En tales casos el artículo 86.1 LC impone a la Administración concursal —con independencia de la comunicación aludida en el artículo $85 \mathrm{LC}-\mathrm{la}$ valoración de todos los créditos que le han sido puestos de manifiesto en el procedimiento por cualquier medio. Sin embargo, para el caso en que el crédito en cuestión no conste de ningún modo en el concurso, y el acreedor lo comunique expirado el plazo de un mes desde la última publicación del Auto de declaración del concurso, pero con anterioridad a la finalización del plazo para que la Administración concursal entregue el informe al Juzgado, la consecuencia para tal crédito será la de su postergación a crédito subordinado. 
QUINTO.-La contienda que se suscita en el presente incidente gira en torno a la última de las hipótesis más arriba apuntadas. Se trata del caso de falta de insinuación del crédito, esto es, bien no comunicado, bien comunicado con posterioridad a la finalización del plazo para la entrega del informe para la Administración concursal. En este caso debemos entender que, a los efectos del concurso, el crédito ha desaparecido y por tanto el acreedor pierde el derecho a ser reintegrado con cargo a la masa activa, y queda privado de todos los derechos que el reconocimiento del crédito le conferiría en el concurso. Esta solución viene avalada por una correcta interpretación de los artículos 85.1, 86.1 y 92.1. ${ }^{\circ}$, todos ellos de la Ley Concursal. Ninguna duda puede plantearse sobre la conducta que la Ley impone a los acreedores que pretendan ver reconocido su crédito. El artículo 85.1 LC exige su insinuación. Insinuación que si bien no se constituye en conducta a la que se pueda compeler obligatoriamente al acreedor, la Ley anuda graves consecuencias para el caso de no observarse. El artículo 86.1 LC impone a la Administración concursal la obligación de decidir sobre la exclusión o inclusión -y en este caso, la cuantificación y la clasificación-de todos los créditos que: a) hayan sido comunicados expresamente; b) resulten de los libros y documentos del deudor; o c) de cualquier otra forma consten en el concurso. Obviamente, quedan fuera de tal obligación aquellos créditos que no se encuentren en ninguno de los tres supuestos enumerados. Llegados a este punto, la Ley lleva a cabo una nueva distinción que ya ha sido examinada en el anterior fundamento jurídico pero que conviene recordar. Dentro de los créditos comunicados expresamente, se discrimina a aquéllos que lo han sido después de vencido el plazo para la insinuación. A éstos, de comunicación tardía, se les atribuye la calificación de subordinados (artículo 92.1. ${ }^{\circ} \mathrm{LC}$ ). Sin embargo, el artículo 92.1 LC también prevé la calificación como créditos subordinados de aquéllos que «no habiendo sido comunicados oportunamente, sean incluidos en dicha lista por el Juez al resolver sobre la impugnación de ésta». Pudiera parecer que esta mención abre la vía para que aquellos créditos que no han sido en absoluto comunicados pudieran llegar a formar parte de la lista de acreedores por el trámite de la impugnación de la lista de acreedores. Entendemos que sostener esta tesis supone atribuir al cauce de impugnación de la lista de acreedores una virtualidad distinta a la que la Ley establece. En efecto, impugnar significa, según el Diccionario de la Real Academia Española, "combatir, contradecir, refutar». Esta contradicción precisa necesariamente de dos opiniones que previamente han sido contrapuestas. Y no hay contraposición de posturas relacionadas con la confección de la lista 
de acreedores - que se impugna - si el acreedor no ha insinuado previamente su crédito en el concurso. De ahí que el artículo 96.3 LC deba ser interpretado en el sentido de que la impugnación de la lista de acreedores podrá consistir en la inclusión de créditos, refiriéndose a aquéllos que han sido previamente excluidos; o a la exclusión de créditos, respecto de los que han sido incluidos en la lista de acreedores, pero no podrá consistir en otra cosa. No puede mantenerse la tesis de que el artículo 92.1 LC abre una nueva vía -en este caso judicial_ para el reconocimiento de créditos porque dicho precepto hace referencia a los créditos que no han sido comunicados "oportunamente». La "comunicación oportuna" no puede referirse a otra comunicación que no sea la prevista en el artículo 85.1 LC. Cualquier otra comunicación no podría verse calificada legalmente como oportuna. Hemos dicho que el artículo 92.1 LC no tiene como finalidad abrir un nuevo cauce para el reconocimiento de créditos, porque su fin es establecer reglas para la calificación de determinados créditos como subordinados.

Entendemos que cuando el artículo 92.1 LC hace alusión tanto a créditos comunicados tardíamente como a créditos no comunicados oportunamente, se está refiriendo a un mismo supuesto de hecho. La diferencia radica en la situación de tales créditos comunicados tardíamente. En el primer caso se trata de créditos que la Administración concursal va a reconocer y por ello a incluir en la lista de acreedores. En este supuesto la regla para la clasificación de tales créditos se dirige a la Administración concursal. En el segundo caso se trata de créditos no comunicados oportunamente - dentro del plazo del artículo 21.1.5 LC, pero sí dentro del de confección del informe por la Administración concursal-pero que, a pesar de todo, y consecuencia de la valoración efectuada por la Administración concursal según lo previsto en el artículo $86.1 \mathrm{LC}$, no han sido incluidos en la lista de acreedores. En esta hipótesis, la regla de valoración va dirigida al órgano judicial. Se trata de créditos que si a consecuencia de la impugnación procede que sean incluidos en la lista de acreedores, tendrán la consideración de subordinados precisamente como consecuencia de su tardía, pero al fin necesariamente expresa insinuación. De ahí que ambas hipótesis previstas en el artículo 92.1 LC sean calificables como comunicaciones tardías de créditos. De ahí que, para los créditos no insinuados dentro del término concedido a la Administración concursal para la presentación del informe, como ocurre con el de la entidad Zahonero, S.L. excluida la posibilidad de su calificación como de subordinados, no pueda ser otra la consecuencia que la de su exclusión definitiva del concurso». 
Es interesante, también, el Auto del Juzgado de lo mercantil N. ${ }^{\circ} 1$ de Madrid, de fecha diez de marzo de dos mil cinco: «FUNDAMENTOS JURIDICOS. PRIMERO.-El artículo 74.1 de la Ley 22/2003, de 9 de julio, Concursal (en adelante LC), impone - en el ámbito del concurso ordinario- a la administración concursal el deber de presentar el informe en el plazo de dos meses a contar desde la aceptación del cargo de al menos dos de sus miembros. La Ley prevé la posibilidad de prorrogar dicho plazo por un mes más, a solicitud de la propia administración concursal siempre y cuando se justifique la concurrencia de circunstancias extraordinarias (artículo 74.2 LC). Con dicho informe se acompañará, por lo que aquí interesa, la lista de acreedores del concursado (artículo 75.2.2. ${ }^{\circ}$ LC). Para que en la lista de acreedores se vean reflejados todos los que ostentan algún crédito concursal contra el deudor, la Ley establece una serie de mecanismos. Por un lado, el artículo 21.4 LC determina que la administración concursal comunicará individualmente a cada uno de los acreedores que consten en el concurso el deber de comunicar sus créditos, de conformidad con lo previsto en el artículo 85 LC. Con independencia de tal comunicación, el artículo 21.1.5. ${ }^{\circ} \mathrm{LC}$ regula el plazo en el que los distintos acreedores del concursado deberán poner en conocimiento de la administración concursal su crédito a los efectos de ser incluidos en la lista de acreedores. De este modo, se concede a todos los acreedores del concursado el plazo de un mes a contar desde la última de las publicaciones obligatorias acordadas en el Auto de declaración del concurso, a fin de que comuniquen a la administración concursal la existencia de sus créditos. Como es fácil de observar, el plazo para que los acreedores comuniquen sus créditos a la administración concursal no tiene por qué coincidir necesariamente con la finalización del periodo que tiene la administración concursal para elaborar el informe. Más bien la situación adecuada debería ser la de que el plazo para la comunicación de crédito finalizara con antelación a la expiración del plazo para la confección y entrega del informe de la administración concursal. Y a tal fin todos los operadores en el concurso deberán proceder de forma que las cosas sean así.

SEGUNDO.-Visto lo anterior, las hipótesis que podemos contemplar a los efectos de comunicación de créditos son las tres siguientes: a) que el acreedor comunique su crédito a la administración concursal dentro del plazo del mes previsto en el artículo 21.1.5. ${ }^{\circ}$ LC; b) que el acreedor comunique su crédito a la administración concursal una vez. transcurrido el plazo del mes previsto en el artículo 21.1.5. ${ }^{\circ} \mathrm{LC}$, pero con anterioridad a la expiración del plazo que la administración tiene 
para la entrega del informe - o el prorrogado- según lo previsto en los artículos 74 y 191 LC; c) que el acreedor comunique su crédito a la administración concursal transcurrido el plazo para que la administración concursal presente su informe. En el primer caso, que debe ser el supuesto normal, la consecuencia es que la administración concursal examinará la solicitud presentada por el acreedor junto con la documentación aportada, y valorará según las normas para la determinación de la masa pasiva la procedencia o improcedencia de su inclusión en la lista de acreedores y con qué eficacia (artículo 86.1 LC).

TERCERO.-El segundo supuesto se corresponde con lo que la Ley califica comunicación tardía de créditos. Las consecuencias que el artículo 92.1 LC anuda a la comunicación tardía de créditos ponen de relieve la importancia para el acreedor de comunicar su crédito dentro del plazo que la Ley le concede. No podemos desconocer que el artículo 86.1 LC impone a la administración concursal la valoración de todos los créditos que le han sido puestos de manifiesto en el procedimiento, tanto de los que se le hayan comunicado expresamente, como de los que resulten de los libros y documentos del deudor o por cualquier otra razón consten en el concurso. Sin embargo, para el caso en que el crédito en cuestión no conste de ningún modo en el concurso y el acreedor lo comunique expirado el plazo de un mes desde la última publicación del Auto de declaración del concurso y con anterioridad a la finalización del plazo para que la administración concursal entregue el informe al Juzgado, la consecuencia para tal crédito será la de su postergación a crédito subordinado.

CUARTO.-El último de los supuestos que hemos enumerado en el segundo fundamento de esta resolución es el de la comunicación del crédito con posterioridad a la entrega del informe por parte de la administración concursal. Se corresponde con el caso que se nos plantea, como consecuencia de la comunicación efectuada por la entidad Telefónica de España, S.A.U. Estamos ante la situación en la que el acreedor ha comunicado su crédito con posterioridad a la entrega por parte de la administración concursal del informe en cuya lista de acreedores no figura el referido crédito, toda vez que consta en autos que la fecha de la última publicación del Auto de declaración del concurso es la del 27 de noviembre de 2004, el informe de la administración concursal fue presentado el día 29 de diciembre de 2004, y el escrito de comunicación del crédito fue presentado por Telefónica de España, S.A.U. el día 25 de febrero de 2005. En este caso debemos entender que, a los efectos del concurso, el crédito ha desaparecido y por tanto el acreedor pierde el derecho a ser reintegrado con cargo a la masa activa, y queda privado de todos los derechos que el reconocimiento del crédito 
le conferiría en el concurso. Y ello sin perjuicio de que dicho acreedor pueda articular los mecanismos procesales que entienda convenientes a los efectos de obtener el reconocimiento de su crédito, lo cual viene abonado por la previsión del artículo 134 LC, el cual extiende, en su caso, los efectos del convenio también a aquellos acreedores que por cualquier causa no hubiesen sido reconocidos como tales en el concurso. De ahí que, habida cuenta del momento procesal en que se encuentra el concurso, y sobre la base de lo razonado en la presente resolución, deba rechazarse a todos los efectos la comunicación del crédito efectuada por la entidad Telefónica de España, S.A.U. mediante el escrito presentado en fecha 25 de febrero de 2005, sin que proceda atribuir a tal comunicación efecto legal alguno en el concurso.

Vistos los preceptos legales citados y demás de general y pertinente aplicación, DISPONGO.-Se inadmite la comunicación del crédito efectuada por la entidad Telefónica de España, S.A.U. mediante el escrito presentado en fecha 25 de febrero de 2005, al que no se le atribuirá ninguna eficacia en el presente concurso».

\subsubsection{PUBlicidad E IMPUGNACIÓN DEL INFORME}

El art. 95, sobre publicidad del informe y de la documentación complementaria, dispone: "1. La administración concursal, simultáneamente a la presentación del informe, dirigirá comunicación personal, por cualquier medio que acredite su recibo, a cada uno de los interesados que hayan sido excluidos, incluidos sin comunicación previa del crédito o por cuantía inferior o con calificación distinta a las pretendidas, indicándoles estas circunstancias y señalándoles un plazo de diez días desde su recibo para que formulen las reclamaciones que tengan por conveniente». Este precepto impone dicho deber de comunicación a la administración concursal, simultáneamente a la presentación de su informe ex art. 75, es decir, el mismo día, por fax, burofax, e-mail, correo certificado con acuse de recibo, etc., pero no a todos los interesados en el concurso sino solamente a los acreedores que hayan sido excluidos, o incluidos sin que hubiesen insinuado su crédito, o incluidos por cuantía inferior a la que reclamaron, o incluidos con calificación distinta a la que pretendieron, explicándoles la situación que les afecta y concediéndoles un plazo de diez días, desde que reciban dicha notificación, para que formulen las reclamaciones que a su derecho convenga. Me parece que el trámite relatado, sobre el plazo de diez días para que los acreedores puedan formular las reclamaciones que a su derecho convenga, no pugna con el establecido en el art. 96.1, concordante con el apartado 2, que se refiere exclusivamente a otros interesados. 
El artículo 96.1 dispone que cualquier interesado podrá impugnar el inventario y la lista de acreedores, dentro del plazo de diez días, a contar desde la publicación ordenada en el citado art. 95.2, a cuyo fin podrá obtener copia a su costa. Naturalmente, aquí se reconoce el derecho de cualquier interesado, entre los que también se encuentran los referidos en el art. 95.1, para impugnar el inventario y la lista de acreedores, y para ello disponen de un plazo de diez días, que nada tiene que ver con el anunciado en la comunicación de la administración concursal ex art. 95.1, sino con la del art. 95.2, que se remite al mencionado art. 23 de la Ley. Se concreta el plazo para reclamar a los acreedores que reciban comunicación de la administración concursal, respecto de los otros interesados, sin discriminación alguna. No obstante, estos mismos acreedores o presuntos acreedores, que hayan recibido la comunicación de la administración concursal, por imperativo del art. 95.1, tienen derecho a impugnar el inventario y otros créditos incluidos o excluidos de la lista de acreedores presentados por la administración concursal, y dispondrán del plazo establecido en el art. 96.1, es decir, de diez días hábiles. No es pacífica la interpretación relativa al derecho de impugnación que confiere a los acreedores la comunicación de la administración concursal ex art. 95.1, pues menciona reclamación, y opiniones autorizadas consideran que se refiere a reclamaciones ante la administración concursal, no a impugnaciones ante el juzgado, aunque tales reclamaciones carecerían de eficacia concursal, salvo que permitiesen a la administración concursal impugnar su propio informe, a la vista de las reclamaciones recibidas, legitimados como cualquier interesado (art. 96.1).

Dispone el art. 96.4: «Las impugnaciones se sustanciarán por los trámites del incidente concursal pudiendo el juez de oficio acumularlas para resolverlas conjuntamente. Dentro de los cinco días siguientes a la notificación de la última sentencia resolutoria de las impugnaciones, la administración concursal introducirá en el inventario, en la lista de acreedores y en la exposición motivada de su informe las modificaciones que, en su caso, procedan y presentará al juez los textos definitivos correspondientes así como una relación actualizada de los créditos contra la masa devengados y pendientes de pago, todo lo cual quedará de manifiesto en la secretaría del juzgado». Cuando sea estimada alguna demanda incidental de impugnación del inventario o de la lista de acreedores, la administración concursal introducirá en el inventario, en la lista de acreedores y en la exposición motivada de su informe las modificaciones que, en su caso, procedan y presentará al juez los textos definitivos correspondientes, etc., dentro de los cinco días siguientes a la fecha en que reciban la notificación de la última sentencia resolutoria de las impugnaciones. 
Omite la Ley la tramitación de referido texto definitivo, pero parece razonable que dé lugar a una Diligencia de Ordenación, para su unión a autos (¿sección segunda?) y consiguiente Providencia judicial de traslado a partes personadas ¿sujeta a recurso de reposición? Parece que sí, pues el texto definitivo presentado por la administración concursal puede contener errores u omisiones.

\subsection{Propuesta de convenio anticipado (trámite escrito)}

Desde la solicitud de concurso voluntario o desde la declaración de concurso necesario y, en ambos casos, hasta la expiración del plazo de comunicación de créditos [un mes ex art. 21.1.5. ${ }^{\circ}$, desde la declaración de concurso], el deudor, que no hubiese pedido la liquidación y no se hallare afectado por alguna de las prohibiciones establecidas en el artículo 105, podrá presentar ante el juez propuesta anticipada de convenio (art. 104.1). Conviene recordar que en procedimiento abreviado el plazo establecido será de quince días (arts. 190 y 191).

Admitida a trámite la propuesta anticipada de convenio, el juez dará traslado de ella a la administración concursal para que, en un plazo no superior a diez días, proceda a su evaluación (art. 107.1), que tiene posibles efectos obstativos a su tramitación escrita, según el art. 107.2: «La administración concursal evaluará el contenido de la propuesta de convenio en atención al plan de pagos y, en su caso, al plan de viabilidad que la acompañen. Si la evaluación fuera favorable, se unirá al informe de la administración concursal. Si fuese desfavorable o contuviere reservas, se presentará en el más breve plazo al juez, quien podrá dejar sin efecto la admisión de la propuesta anticipada o la continuación de su tramitación con unión del escrito de evaluación al referido informe». Texto confuso sobre el plazo que dispone la administración concursal para informar sobre la propuesta de convenio anticipado, aunque considero debe cumplir el señalado en la providencia judicial de traslado, es decir, en un plazo no superior a diez días, sin que venga a cuento su presentación en el más breve plazo, si fuese desfavorable. Conviene recordar que en procedimiento abreviado el plazo establecido será de cinco días (arts. 190 y 191).

Desde la admisión a trámite de la propuesta anticipada de convenio y hasta la expiración del plazo de impugnación del inventario y de la lista de acreedores, es decir, hasta diez días después de la comunicación del informe de la administración concursal, según el art. 95.1, o dentro del plazo de diez días, a contar desde la publicación ordenada en el citado art. 95.2, cualquier acreedor podrá manifestar su adhesión a la propuesta, con los requisitos y en la forma establecidos en la Ley 
(art. 108.1). Conviene recordar el art. 96 de la Ley Concursal: «Impugnación del inventario y de la lista de acreedores. 1. Dentro del plazo de diez dias a contar desde la comunicación a que se refiere el apartado 2 del artículo anterior, cualquier interesado podrá impugnar el inventario y la lista de acreedores, a cuyo fin podrá obtener copia a su costa». El mencionado apartado 2 del art. 95 dispone: «La presentación al juez del informe de la administración concursal y de la documentación complementaria se comunicará de acuerdo con lo dispuesto en el artículo $23^{6}$ y se publicará en el tablón de anuncios del juzgado», es decir, tendrá lugar la denominada publicidad noticia.

Cierra la fase común, aunque se incorpora como primer precepto de las fases de convenio o de liquidación, el artículo 98: «Resolución judicial. Transcurrido el plazo de impugnación del inventario y de la lista de acreedores sin que se hubieren presentado impugnaciones o, de haberse presentado, una vez puestos de manifiesto en la secretaría del juzgado los textos definitivos de aquellos documentos, el Juez dictará la resolución que proceda de conformidad con lo dispuesto en este título».

\section{Fase de convenio}

Si no procediera la aprobación de la propuesta anticipada de convenio, tramitada por escrito, el juez requerirá de inmediato al deudor para que, en plazo de tres días, manifieste si mantiene dicha propuesta para su sometimiento a la junta de acreedores o desea solicitar la liquidación (art. 110.1), salvo que hubiese solicitado la liquidación, en el mismo escrito de presentación de la propuesta anticipada de convenio, para el caso de que no prosperara ${ }^{7}$. Conviene recordar que en procedimiento abreviado el plazo establecido será dos días (arts. 190 y 191).

6 «1. La publicidad de la declaración de concurso, así como de las restantes notificaciones, comunicaciones y trámites del procedimiento, podrá realizarse por medios telemáticos, informáticos y electrónicos, en la forma que reglamentariamente se determine, garantizando la seguridad y la integridad de las comunicaciones. No obstante lo anterior, la declaración del concurso se anunciará en el "Boletín Oficial del Estado" y en un diario de los de mayor difusión en la provincia donde el deudor tenga el centro de sus principales intereses, así como en uno de los de mayor difusión en la provincia donde radique su domicilio. Estos anuncios contendrán los datos suficientes para identificar el proceso y las formas de personarse en él. La publicación en el "Boletín Oficial del Estado" y, en su caso, en otros periódicos oficiales del edicto se insertará con la mayor urgencia».

7 Rojo, Angel, El convenio anticipado, Madrid, Civitas, 2004, pág. 33. 


\subsection{Propuestas de convenio ordinario}

Cuando el concursado no hubiere solicitado la liquidación y no haya sido aprobada ni mantenida la propuesta anticipada de convenio, el juez, dentro de los quince días siguientes a la expiración del plazo de impugnación del inventario y de la lista de acreedores (art. 96.1), si no se hubiesen presentado impugnaciones o, de haberse presentado, a la fecha en que se pongan de manifiesto en la secretaría del juzgado los textos definitivos de aquellos documentos ${ }^{8}$ (art. 96.4), dictará auto poniendo fin a la fase común del concurso, abriendo la fase de convenio ordinario y ordenando la formación de la sección quinta, relativa al convenio o a la liquidación (art. 111.1).

\subsection{Junta de acreedores}

Cuando el concursado hubiera mantenido la propuesta anticipada de convenio, el juez, sin necesidad de nueva resolución sobre dicha propuesta ni de informe de la administración concursal, dictará auto convocando la junta de acreedores (art. 111.2). Dicho auto ordenará convocar junta de acreedores, de acuerdo con lo establecido en el artículo 23 (publicidad), fijando lugar, día y hora de la reunión. Cuando se trate del supuesto previsto en el artículo 110 [mantenimiento de la propuesta anticipada de convenio] y en el apartado 1 del artículo 113 [propuestas de convenio normal u ordinario por el concursado o los acreedores, antes de la convocatoria de la junta de acreedores], la junta deberá ser convocada para su celebración dentro del segundo mes contado desde la fecha del auto. En los demás casos [propuestas de convenio presentadas por el concursado o por los acreedores después de la convocatoria de dicha junta], deberá ser convocada para su celebración dentro del tercer mes contado desde la fecha del referido auto que convoque a la junta de acreedores y no será computable agosto.

\subsection{Presentación de propuestas de convenio}

Transcurrido el plazo de comunicación de créditos, es decir, un mes desde la última de las publicaciones obligatorias del auto de declaración de concurso (art. 85.1, que se remite al art. 21.1.5. ${ }^{\circ}$ ), y hasta la fi-

8 Se refiere al informe definitivo de la administración concursal, que presentará al juzgado en el plazo de cinco días siguientes a la notificación de la última sentencia resolutoria de las impugnaciones habidas. 
nalización del plazo de impugnación del inventario y de la lista de acreedores, que expira a los diez días de la comunicación del informe de la administración concursal (art. 96.1), si no se hubiesen presentado impugnaciones o, de haberse presentado, hasta la fecha en que se pongan de manifiesto en la secretaría del juzgado los textos definitivos de aquellos documentos, elaborados por la administración concursal (art. 96.4), podrá presentar propuesta de convenio el concursado, que no hubiere presentado propuesta anticipada ni tuviere solicitada la liquidación. También podrán hacerlo los acreedores, cuyos créditos consten en el concurso y superen, conjunta o individualmente, una quinta parte del total pasivo resultante de la lista definitiva de acreedores ${ }^{9}$, salvo que el concursado tuviese solicitada la liquidación (art. 113.1). Consecuentemente, las posibilidades que ofrece este precepto al concursado y a los acreedores, de presentación de propuestas de convenio, tienen lugar dentro de la fase común, momento procesal en el que puede suceder que aún no se haya formado la masa pasiva ni la clasificación de los créditos concursales.

En el supuesto de que no hubiera sido presentada ninguna propuesta de convenio, de las comentadas en el párrafo anterior, ni se hubiese solicitado la liquidación por el concursado, éste y los acreedores, cuyos créditos superen, conjunta o individualmente, una quinta parte del total pasivo resultante de la lista definitiva ${ }^{10}$, podrán presentar propuestas de convenio desde la convocatoria de la junta hasta cuarenta días antes de la fecha señalada para su celebración (art. 113.2). Es decir, una vez abierta la fase de convenio, que supone la constancia en autos de la masa pasiva y la clasificación de créditos, permitiendo el conocimiento de los créditos subordinados.

Dentro de los cinco días siguientes a su presentación, el juez admitirá a trámite las propuestas de convenio, si cumplen las condiciones de tiempo (art. 113), forma (art. 99) y contenido (art. 100) establecidas en la Ley Concursal. De apreciar algún defecto, dentro del mismo plazo, lo notificará al concursado o, en su caso, a los acreedores para que, en los tres días siguientes a la notificación, puedan subsanarlo (dos días en el concurso abreviado), según el art. 114.

En la misma providencia de admisión a trámite se acordará dar traslado de la propuesta de convenio a la administración concursal para

9 Documento que puede no obrar aún en autos, cuando se presentasen propuestas de convenio por los acreedores, antes de la presentación por la administración concursal de su informe ex art. 75 .

10 Durante este plazo de presentación de propuestas de convenio por los acreedores, ya obra en autos la lista definitiva de acreedores. 
que, en el plazo improrrogable de diez días, emita escrito de evaluación sobre su contenido, en relación con el plan de pagos y, en su caso, con el plan de viabilidad que la acompañe. Los escritos de evaluación emitidos antes de la presentación del informe de la administración concursal se unirán a éste, conforme al apartado 2 del artículo 75, y los emitidos con posterioridad se pondrán de manifiesto en la secretaría del juzgado desde el día de su presentación al juez (art. 115).

Los acreedores podrán adherirse en trámite escrito, mediante comparecencia judicial o instrumento público, a cualquier propuesta de convenio ordinario, en los plazos y con los efectos establecidos en la Ley Concursal (art. 115.3, concordante con lo dispuesto en el art. 103), es decir, hasta el momento de cierre de la lista de asistentes a la junta.

\subsection{Oposición al convenio aprobado}

Podrá formularse oposición a la aprobación judicial del convenio, caso de propuesta anticipada, en el plazo de diez días, contado desde el siguiente a la fecha en que el juez haya verificado que las adhesiones presentadas alcanzan la mayoría legal para la aceptación del convenio, o desde la fecha de conclusión de la junta, cuando en ella se acepte una propuesta de convenio (cinco días en procedimiento abreviado).

Si la infracción apreciada afectase a la forma y contenido de algunas de las adhesiones (art. 103), el juez, mediante auto, concederá el plazo de un mes (quince días en procedimiento abreviado) para que aquéllas se formulen con los requisitos y en la forma establecidos en la Ley, transcurrido el cual dictará la oportuna resolución (art. 131.2).

\subsection{Cumplimiento de convenio}

Con periodicidad semestral (¿trimestralmente en procedimiento abreviado?), contada desde la fecha de la sentencia aprobatoria del convenio, el deudor informará al juez del concurso acerca de su cumplimiento (art. 138).

El deudor, una vez que estime íntegramente cumplido el convenio, presentará al juez del concurso el informe correspondiente con la justificación adecuada y solicitará la declaración judicial de cumplimiento. El juez acordará poner de manifiesto en la secretaría del juzgado el informe y la solicitud. Transcurridos quince días (ocho días en procedimiento abreviado) desde la puesta de manifiesto, el juez, si estimare cumplido el convenio, lo declarará mediante auto, al que dará la misma publicidad que a su aprobación ex arts. 23 y 24 (art. 139). 


\subsection{Incumplimiento de convenio}

Cualquier acreedor que estime incumplido el convenio, en lo que le afecte, podrá solicitar del juez la declaración de incumplimiento, en el plazo de dos meses (un mes en procedimiento abreviado) desde que se publique el auto de cumplimiento de convenio, que se tramitará por el cauce del incidente concursal, contra cuya sentencia cabe recurso de apelación, y si se declarase el incumplimiento supondrá la rescisión del convenio y la desaparición de los efectos de quita y espera ex art. 136 (art. 140), así como la apertura de oficio de la liquidación, según el art. 143.1.5. ${ }^{\circ}$.

\subsection{Conclusión del concurso}

Firme el auto de declaración de cumplimiento del convenio y transcurrido el plazo de caducidad de las acciones de declaración de incumplimiento (dos meses, según el art. 140.1, o uno, en procedimiento abreviado) o, en su caso, rechazadas por resolución judicial firme las que se hubieren ejercitado, el juez dictará auto de conclusión del concurso, al que se dará la publicidad prevista en los artículos 23 y 24 (art. 141).

\section{Fase de liquidación}

La liquidación de los bienes y derechos integrados en la masa activa del concurso y la aplicación de su producto a la satisfacción de los créditos contra la masa y concursales es causa de conclusión del concurso, entre las previstas en el art. 176 de la nueva Ley ${ }^{11}$. Su tramitación procesal tiene lugar en la sección quinta del procedimiento (art. $183.5^{\circ}$ ) y se regula en el capítulo II del Título V de la citada Ley (arts. 142 a 162). A esta fase de liquidación se llega una vez finalizada la fase común (art. 142.2), directamente o después de frustrados los intentos de convenio (art. 143.1.2. $.^{\circ} 3 .^{\circ}$ y $4 .^{\circ}$ ) o ante el riesgo de su incumplimiento (art. 142.3 y 4), así como una vez declarado dicho incumplimiento (art. 143.1.5..$^{\circ}$.

La apertura de la fase de liquidación, que la exposición de motivos considera solución alternativa y subsidiaria en el concurso, puede ser declarada por resolución judicial, a petición del deudor, de cualquier acreedor o de oficio.

11 LEY 22/2003, de 9 de julio, concursal (BOE número 164, de 10 de julio). 
El deudor podrá pedir la liquidación, según el art. 142.1: 1. ${ }^{\circ}$ Con la solicitud de concurso voluntario, concordante con el art. $6.4^{12}$, a la que acompañará propuesta de plan de liquidación; $2 .^{\circ}$ Desde que se dicte el auto de declaración de concurso y hasta la expiración del plazo de impugnación del inventario y de la lista de acreedores, si no se hubiesen presentado impugnaciones (diez o cinco días desde la comunicación del informe regulado en el art. 96, cuya publicidad se ordena en el art. 97), $\mathrm{o}$, de haberse presentado, hasta la fecha en que se pongan de manifiesto en la secretaría del juzgado los textos definitivos de aquellos documentos (art. 96.4), siempre que al momento de la solicitud no hubiera presentado propuesta de convenio o, de haber presentado una anticipada, se hubiese denegado su admisión a trámite; $3{ }^{\circ} \mathrm{Si}$ el deudor no mantuviese la propuesta anticipada de convenio, de conformidad con lo previsto en el apartado 1 del artículo 110, que le faculta para solicitar la liquidación; y, $4 .^{\circ}$ Dentro de los cinco o tres días siguientes a aquél en que los acreedores hayan presentado propuesta de convenio, conforme al apartado 1 del artículo 113, salvo que el propio deudor hubiere presentado una suya. Se observa que la petición de liquidación por el deudor, en los supuestos descritos, tiene lugar durante la fase común del concurso.

Sin embargo, la Ley confiere al concursado la facultad de solicitar la apertura de la fase de liquidación durante la fase de convenio, según previene el art. 128.3, en el plazo de diez días (cinco días en el procedimiento abreviado), contados desde la fecha de conclusión de la junta de acreedores que aceptó una propuesta de convenio presentada por acreedores, a la que él no le hubiese prestado conformidad.

\subsection{Plan de liquidación}

El artículo 148 establece: «1. Dentro de los quince días siguientes al de notificación de la resolución de apertura de la fase de liquidación a la administración concursal, presentará ésta al Juez un plan para la realización de los bienes y derechos integrados en la masa activa del concurso que, siempre que sea factible, deberá contemplar la enajenación unitaria del conjunto de los establecimientos, explotaciones y cualesquiera otras unidades productivas de bienes y servicios del concursado o de algunos de ellos...». Breve plazo, cuando la masa activa sea de mayor cuantía, aunque pueda prorrogarse por otros quince días, y brevísimo si de procedimiento abreviado se tratase (ocho días), según el art. 191.1.

12 «En el supuesto previsto en el artículo 142.1.1. ${ }^{\circ}$ deberá acompañarse propuesta de plan de liquidación». 
Además de su puesta de manifiesto en la Secretaría del Juzgado y en otros lugares que el Juez acuerde, se dará traslado de dicho plan de liquidación al deudor y a los acreedores personados, así como a los trabajadores, en su caso, para alegaciones, durante los quince días siguientes (ocho días en procedimiento abreviado), según los apartados 2 y 3 del citado art. 148. Si se hubiesen formulado alegaciones, la administración concursal informará, en el plazo de diez días (cinco días en procedimiento abreviado), sobre las observaciones y propuestas formuladas.

El apartado 4 del citado art. 148 contempla el caso de que las operaciones de liquidación previstas supongan la extinción o suspensión de contratos laborales o la modificación de las condiciones de trabajo y declara la aplicación del art. 64, antes de la elaboración del plan, es decir, la administración concursal debe tramitar ante el juez del concurso los expedientes de modificación sustancial de las condiciones de trabajo o de suspensión o extinción colectiva de relaciones laborales, quien llamará a consulta a los representantes de los trabajadores y recabará informe de la Autoridad Laboral. Esta incidencia puede dar al traste con el plazo de quince días (ocho días en procedimiento abreviado) y su prórroga, pues parece que se suspende el mismo, en tanto en cuanto no se resuelva la problemática laboral.

\subsection{Informe}

El informe sobre el estado de las operaciones de liquidación, cada tres meses desde su apertura (un mes y quince días en procedimiento abreviado), detallará las gestiones sobre realización de la masa activa y los ingresos devengados, así como los obtenidos, y de igual modo dará cuenta de los gastos devengados y de los pagos satisfechos. Considero que resulta más coherente como dies a quo, para inicio del cómputo trimestral, la fecha del auto aprobatorio del plan de liquidación.

Dispone el art. 153: «1. Transcurrido un año desde la apertura de la fase de liquidación sin que hubiera finalizado ésta, cualquier interesado podrá solicitar al juez del concurso la separación de los administradores concursales y el nombramiento de otros nuevos...» (seis meses en procedimiento abreviado). Se señala como dies a quo, para el cómputo del plazo anual o semestral, la apertura de la fase de liquidación, cuando lo coherente hubiese sido computar la fecha de comunicación a la administración concursal del auto de aprobación del plan de liquidación o de aplicación de las reglas legales supletorias. Recuerdo que parte de este plazo anual puede haberse consumido en las gestiones laborales previstas en el art. 148.4. 


\section{Calificación del concurso}

La calificación del concurso, como fortuito o culpable, es pieza decisiva, cuando tenga lugar su formación, en la que se evaluará la conducta del deudor, en los dos años anteriores a la declaración judicial y con posterioridad, es decir, durante la tramitación del procedimiento.

\subsection{Informe de la administración concursal}

El artículo 169.1 establece que la administración concursal, dentro de los quince días siguientes al de expiración de los plazos para la personación de los interesados, presentará al Juez un informe razonado y documentado sobre los hechos relevantes (artículos 164 y 165) para la calificación del concurso, con propuesta de resolución, y si la propuesta fuese como culpable expresará la identidad de las personas a las que deba afectar la calificación (el deudor o, si los tuviere, sus representantes legales y, en caso de persona jurídica, sus administradores o liquidadores, de derecho o de hecho) y la de las que hayan de ser consideradas cómplices, justificando la causa, así como la determinación de daños y perjuicios que, en su caso, se hayan causado por las personas anteriores. Insuficiente plazo, a mi juicio, dado el riguroso estudio que requiere y la trascendencia de este informe, con posibles consecuencias civiles e incluso penales para el deudor y terceros, como se deduce del contenido de la sentencia de calificación (art. 172.2). Conviene recordar que en procedimiento abreviado el plazo establecido será de ocho días (arts. 190 y 191).

\subsection{Informe del Ministerio Fiscal}

Del referido informe de la administración concursal se dará traslado al Ministerio Fiscal, para que emita dictamen sobre la calificación del concurso, en el plazo de diez días (cinco días en procedimiento abreviado). Si el Ministerio Fiscal no emitiera dictamen, se entenderá conforme con la propuesta de calificación.

Cuando en alguno de los dos informes mencionados se hubiese calificado el concurso como culpable, el juez dará audiencia al deudor por plazo de diez días (cinco días en procedimiento abreviado) y ordenará emplazar a todas las personas que, según resulte de lo actuado, pudieran ser afectadas por la calificación del concurso (el deudor o, si los tuviere, sus representantes legales y, en caso de persona jurídica, sus administradores o liquidadores, de derecho o de hecho o declaradas cómplices, a fin de que, en plazo de cinco días (tres días en procedimiento abreviado), comparezcan en la sección si no lo hubieran hecho con anteriori- 
dad. No parece que sean emplazados los acreedores, ni tan siquiera aquéllos que formularon alegaciones iniciales. A quienes comparezcan en plazo se les dará vista del contenido de la sección para que, dentro de los diez días siguientes (cinco días en procedimiento abreviado), aleguen cuanto convenga a su derecho. Si comparecieren con posterioridad al vencimiento del plazo, se los tendrá por parte sin retroceder el curso de las actuaciones. Si no comparecieren, serán declarados en rebeldía y seguirán su curso las actuaciones sin volver a citarlos.

\section{Clausura y reapertura}

La exposición de motivos menciona: «La ley regula detalladamente las causas de conclusión del concurso, cuya naturaleza puede ser muy diversa: bien porque la apertura no se ajustó a derecho (revocación del auto de declaración de concurso), bien porque el procedimiento alcanzó su finalidad (cumplimiento del convenio, integra satisfacción de todos los acreedores), bien por su frustración (inexistencia de bienes y derechos con los que satisfacer a los acreedores), bien por el ejercicio del derecho de disposición de las partes sobre el procedimiento (desistimiento o renuncia de la totalidad de los acreedores reconocidos, transacción del deudor con ellos, causas éstas que, por sus características, sólo pueden operar una vez terminada la fase común del procedimiento y que exigen aceptación u homologación del juez, previo informe de la administración concursal). En los casos de conclusión por inexistencia de bienes y derechos, del concursado o de terceros responsables, con los que satisfacer a los acreedores, que conservan su derecho a hacer efectiva la responsabilidad del deudor sobre los que en el futuro aparezcan, la ley contempla también la reapertura del concurso, tanto si se trata de deudor persona natural como de persona jurídica. En este último caso, puesto que la conclusión por inexistencia de activos patrimoniales lleva consigo la extinción de la persona jurídica, la reapertura por aparición posterior de bienes y derechos se concretará a liquidarlos; pero si se trata de persona natural, la continuación de su actividad patrimonial habrá podido reflejarse tanto en la aparición de activos como de nuevos pasivos, lo que habrá de tenerse en cuenta en la actualización del inventario y de la lista de acreedores».

\subsection{Clausura}

Artículo 176. "1. Procederá la conclusión del concurso y el archivo de las actuaciones en los siguientes casos:... $3 .^{\circ}$ En cualquier esta- 
do del procedimiento, cuando se produzca o compruebe el pago o la consignación de la totalidad de los créditos reconocidos o la íntegra satisfacción de los acreedores por cualquier otro medio; $4^{\circ}$ En cualquier estado del procedimiento, cuando se compruebe la inexistencia de bienes y derechos del concursado ni de terceros responsables con los que satisfacer a los acreedores; $5^{\circ}$ En cualquier estado del procedimiento, una vez terminada la fase común del concurso, cuando quede firme la resolución que acepte el desistimiento o la renuncia de la totalidad de los acreedores reconocidos».

En estos casos, sigue el apartado 2 del citado art. 176, la conclusión se acordará por auto y previo informe de la administración concursal, que se pondrá de manifiesto por 15 días a todas las partes personadas (ocho días en procedimiento abreviado). El informe de la administración concursal favorable a la conclusión del concurso por inexistencia de bienes y derechos afirmará y razonará inexcusablemente que no existen acciones viables de reintegración de la masa activa ni de responsabilidad de terceros pendientes de ser ejercitadas.

No se establece plazo alguno para la presentación del informe de la administración concursal favorable a la conclusión del concurso, lo cual es lógico, cuando la petición de clausura obedezca al hecho descrito el apartado $4 .^{\circ}$ anterior y fuese iniciativa de la administración concursal. Sin embargo, cuando se inicie de oficio o a petición de parte interesada (deudor, acreedor, etc.), será la providencia correspondiente la que señale el plazo para emitir el referido informe, que podrá ser favorable, si ratifica la inexistencia de bienes y que no existen acciones viables de reintegración de la masa activa ni de responsabilidad de terceros pendientes de ser ejercitadas, o desfavorable, en caso contrario.

No encuentro sentido a este informe en lo supuestos de los apartados $3 .^{\circ}$ y $5 .^{\circ}$ anteriores, pues nada tienen que ver con la existencia o inexistencia de bienes, etc. Es decir, si se ha producido el pago o la consignación de la totalidad de los créditos reconocidos o la íntegra satisfacción de los acreedores por cualquier otro medio (art. 175.1.3. ${ }^{\circ}$ ), será la administración concursal, que habrá pagado a todos los acreedores concursales y contra la masa, quien solicite la clausura del concurso, queden o no bienes y derechos en la masa activa, etc., los cuales entregará al deudor con su rendición de cuentas (art. 181). En el caso 5. ${ }^{\circ}$ del art. 176.1, será el juez quien dé traslado a la administración concursal de su resolución sobre el desistimiento o la renuncia de la totalidad de los acreedores reconocidos (concursales y contra la masa), y el informe que deberá emitir la administración concursal será favorable, si todos los acreedores concursales y contra la masa han desistido o re- 
nunciado, o desfavorable, caso contrario. No observo relación alguna con inexistencia de bienes y derechos, etc., que de existir serán entregados al deudor con la rendición de cuentas (art. 181).

\subsection{Reapertura}

Artículo 179. «1. La declaración de concurso de deudor persona natural dentro de los cinco años siguientes a la conclusión de otro anterior por inexistencia de bienes y derechos tendrá la consideración de reapertura de éste. El juez competente, desde que se conozca esta circunstancia, acordará la incorporación al procedimiento en curso de todo lo actuado en el anterior. 2. La reapertura del concurso de deudor persona jurídica concluido por inexistencia de bienes y derechos será declarada por el mismo juzgado que conoció de éste, se tramitará en el mismo procedimiento y se limitará a la fase de liquidación de los bienes y derechos aparecidos con posterioridad. A dicha reapertura se le dará la publicidad prevista en los artículos 23 y 24 ».

Aunque se trata de una opción legislativa, llama la atención el límite de cinco años siguientes a la conclusión de otro anterior, por inexistencia de bienes y derechos, para que la declaración de concurso de deudor persona natural tenga la consideración de reapertura de éste. Este plazo se computará a partir de la resolución firme (auto o sentencia) que haya acordado la conclusión del concurso anterior ¿y si hubiesen transcurrido cinco años y un día o más?

La reapertura del concurso de deudor persona jurídica concluido por inexistencia de bienes y derechos, con causa en la aparición de nuevos bienes y derechos, sólo será posible si no hubiesen prescrito las acciones de los acreedores (art. 60).

Artículo 180. "1. Los textos definitivos del inventario y de la lista de acreedores formados en el procedimiento anterior habrán de actualizarse por la administración concursal en el plazo de dos meses a partir de la incorporación de aquellas actuaciones al nuevo concurso». Un mes si de procedimiento abreviado se tratase.

\section{Derecho transitorio concursal}

La Disposición Transitoria Primera de la Ley 22/2003, de 9 de julio, Concursal, se ocupa de los procedimientos concursales que se encuentren en tramitación a la fecha de su entrada en vigor, el uno de septiembre de dos mil cuatro, y dispone que continuarán rigiéndose hasta 
su conclusión por el derecho anterior, es decir, se reconoce el principio general de irretroactividad de las normas legales ${ }^{13}$, aunque con ciertas excepciones, que paso a comentar.

Conviene recordar el Derecho derogado sobre procedimientos concursales, aunque sólo mencionaré las respectivas normas que han estado vigentes hasta el uno de septiembre de dos mil cuatro: «concurso de acreedores» (arts. 1.913 a 1.928 del Código civil y 1.156 a 1.317 de la Ley de Enjuiciamiento Civil de 1881); «quiebra» (arts. 1.319 a 1.396 de la citada LEC; arts. 874 a 941 del Código de Comercio; y, arts. 1.004 a 1.177 del primer C. de C. de 1829); «quita y espera» (arts. 1.912 y 1.917 a 1.920 del Código Civil y arts. 1.130 a 1.155 de la anterior Ley de Enjuiciamiento Civil); y, «suspensión de pagos» (arts. 870 a 873 del Código de Comercio de $1885^{14}$, y Ley especial de 26 de julio de 1922). Además, pueden ser de interés las disposiciones especiales para las suspensiones de pagos y quiebras de las empresas de ferrocarriles y demás servicios públicos (arts. 930 a 941 del C. de C.; Leyes de 12 de noviembre de 1869, 19 de septiembre de 1896, 9 de abril de 1904 y 2 de enero de 1915); y el Decreto de 5 de noviembre de 1934, así como la Ley de 1 de septiembre de 1939, de la Jefatura del Estado, sobre intervención de las empresas y en las condiciones que indica.

13 Art. 2 del Código Civil: «3. Las leyes no tendrán efecto retroactivo si no dispusieren lo contrario». Artículo 2. de la LEC: Aplicación en el tiempo de las normas procesales civiles. "Salvo que otra cosa se establezca en disposiciones legales de Derecho transitorio, los asuntos que correspondan a los tribunales civiles se sustanciarán siempre por éstos con arreglo a las normas procesales vigentes, que nunca serán retroactivas». Art. 9 de la Constitución Española: «3. La Constitución garantiza... la irretroactividad de las disposiciones sancionadoras no favorables o restrictivas de derechos individuales...».

${ }^{14}$ La doctrina mayoritaria ha considerado tácita y parcialmente derogados (derogación implícita, según Guasch Martorell) los arts. 870-872 del C. de Comercio: GonZÁLEZ DE Echávarri, José M. a y Miguel Romero, Mauro, Comentarios a la Ley de Suspensión de Pagos, Valladolid, Imprenta de Emilio Zapatero, sin fecha, pág. 153; TORRES DE CRUELLS, Joaquín, La suspensión de pagos. Barcelona, Bosch, 1957, pág. 83; SAGRERA Tizón, José M. a, Comentarios a la Ley de Suspensión de Pagos. Barcelona, Bosch, 2. ${ }^{\text {a }}$ ed., 1989, Vol. I, págs. 164-166; BisBal MÉNDEZ, Joaquín, La empresa en crisis y el derecho de quiebras, Bolonia, Publicaciones del Real Colegio de España, 1986, págs. 150-151; MASCARELL NAVARro, M. ' José, Aspectos procesales de la Ley de Suspensión de Pagos, Granada, Comares, 1994, págs. 12-13. MENÉNDEZ, Aurelio, «Sobre la reforma del Derecho concursal y el apoyo de los estudios económicos», Revista del Consejo General de la Abogacía Española, Madrid, septiembre 1994, n. ${ }^{\circ}$ 2, págs. 6-7. GuASCH MARTORELL, Rafael, «Aproximación crítica a la protección de la integridad del patrimonio concursal en la Ley de Suspensión de Pagos», Revista de Derecho Mercantil, Madrid, abril-junio 1995 (núm. 216), pág. 520. 


\subsection{Conclusión y reapertura del procedimiento}

El número 1 de la mencionada disposición transitoria primera, como excepción a la declaración general de que los procedimientos concursales en tramitación, a la entrada en vigor de la citada Ley Concursal, continuarán rigiéndose hasta su conclusión por el referido derecho anterior, establece que será de inmediata aplicación lo dispuesto en los artículos 176 a 180 de dicha Ley, que regulan la conclusión ${ }^{15}$ y reapertura ${ }^{16}$ del concurso, excluyendo la aplicación de los incisos $1 .^{\circ} \mathrm{y}$ $2 .^{\circ}$ del apartado 1 del citado art. $176^{17}$, quizá en consideración a que se trata de supuestos comunes de conclusión y archivo de los procedimientos concursales anteriores y del vigente concurso, aunque en el derecho derogado no se dicta auto de declaración de quita y espera.

Trataré de referirme a las actuaciones y plazos de los órganos auxiliares de los citados procedimientos concursales anteriores, aunque puede consultarse un trabajo más completo en la Revista Estudios de Deusto, Vol. 51/2, julio-diciembre 2004, de la Universidad de Deusto.

\subsubsection{CONCLUSIÓN}

La clausura del concurso, prevista en el citado art. 176, podrá iniciarse de oficio por el juez o a instancia de parte interesada, es decir, el deudor y cualquier acreedor ${ }^{18}$, así como de la administración concursal, luego la misma legitimación regirá para solicitar la clausura de los mentados procedimientos anteriores en tramitación, y también podrá iniciarse de oficio por el Juez de Primera Instancia o a solicitud de cualquier acreedor o de los órganos auxiliares (comisario, depositario, síndicos e interventores).

El art. 176.4 preceptúa: «El informe de la administración concursal favorable a la conclusión del concurso por inexistencia de bienes y derechos afirmará y razonará inexcusablemente que no existen acciones

15 La conclusión del concurso se regula también en el art. 141 de la Ley Concursal por cumplimiento de convenio.

${ }_{16}$ Reapertura que parece prevenirse para el supuesto exclusivo de clausura del procedimiento por inexistencia de bienes y derechos (masa activa), en el art. 179.

17 «1. Procederá la conclusión del concurso y el archivo de las actuaciones en los siguientes casos: $1 .^{\circ}$ Una vez firme el auto de la Audiencia Provincial que revoque en apelación el auto de declaración de concurso. $2{ }^{\circ}$ Una vez firme el auto que declare el cumplimiento del convenio y, en su caso, caducadas o rechazadas por sentencia firme las acciones de declaración de incumplimiento.»

18 Art. 3: «1. Para solicitar la declaración de concurso están legitimados el deudor y cualquiera de sus acreedores. Si el deudor fuera persona jurídica, será competente para decidir sobre la solicitud el órgano de administración o de liquidación...». 
viables de reintegración de la masa activa ni de responsabilidad de terceros pendientes de ser ejercitadas...».

Los emisores de este informe serán los síndicos del concurso de acreedores o de la quiebra, en este último procedimiento con la supervisión del comisario, y los interventores de la suspensión de pagos declarada en insolvencia definitiva, cuyo contenido se concreta en este apartado «afirmará y razonará inexcusablemente que no existen acciones viables de reintegración de la masa activa ni de responsabilidad de terceros pendientes de ser ejercitadas», y que podrá ser objeto de alegaciones por las demás partes personadas (deudor y acreedores), es decir, se dará audiencia para alegaciones a las partes personadas.

Las acciones de nulidad y de reintegración en la quiebra, cuya legitimación activa ostenta la sindicatura, con la aprobación de comisario, se regulan en los citados arts. 1.366 a 1.377 de la anterior LEC, que se remiten a los mencionados arts. 878 a 882 del C. de Comercio. En la suspensión de pagos, calificada como insolvencia definitiva, debe acudirse al art. 21 de la referida Ley especial, que se remite a los referidos arts. 879 a 882 del C. de C. En cuanto a las acciones de responsabilidad contra terceros, conviene recordar las específicas contra los administradores de derecho o de hecho, a los que podrá afectar el régimen general de responsabilidad (arts. 133 y 262.5 del TRLSA y arts. 69 y 105.5 de la LSRL) y el previsto en el art. 1.301 de la anterior LEC, para el concurso de acreedores, y en la sección quinta de calificación de la quiebra (art. 1.382 y siguientes de dicha Ley rituaria), que incluye la responsabilidad civil de los cómplices ${ }^{19}$ (art. 893 del C. de C.), así como a través de la pieza separada de la suspensión de pagos declarada en insolvencia definitiva para la calificación y depuración de las responsabilidades en que haya podido incurrir el suspenso (art. 20 de la Ley especial).

Solamente si se prueba el hecho de inexistencia de masa activa, así como cuando se alcance evidencia sobre la inviabilidad de acciones de reintegración de bienes y de responsabilidad contra terceros, podrá proseguirse la tramitación de la clausura del procedimiento concursal.

El art. 176.5 estipula: «Si en el plazo de audiencia concedido a las partes se formulase oposición a la conclusión del concurso, el juez le dará la tramitación del incidente concursal».

19 Los cómplices de la quiebra serán condenados, civilmente, a perder cualquier derecho que tengan sobre la masa (normalmente su crédito) y a reintegrar los bienes y derechos sustraídos, con intereses e indemnización de daños y perjuicios (art. 894 del C. de C.). 
Se entenderá que esta referencia al incidente concursal está hecha al procedimiento del artículo $393^{20}$ de la Ley de Enjuiciamiento Civil, según dispone el inciso segundo del número 1 de la mentada disposición transitoria primera, es decir, que no se tramita el incidente de conformidad con los dispuesto en el capítulo III del título VIII (arts. 192 a 196) de la Ley Concursal. En el concurso, estarán legitimados para formular oposición a la conclusión del concurso la administración concursal, el deudor y los acreedores, que no la hubiesen solicitado. En los procedimientos derogados, además de estos últimos (deudor y acreedores), estarán legitimados para oponerse a su clausura los síndicos del concurso de acreedores o de la quiebra, en esta última con autorización del comisario, y los interventores de la suspensión de pagos, si no la hubiesen instado.

\subsubsection{REAPERTURA}

Dispone el art. 179: 1. "La declaración de concurso de deudor persona natural dentro de los cinco años siguientes a la conclusión de otro anterior por inexistencia de bienes y derechos tendrá la consideración de reapertura de éste. El juez competente, desde que se conozca esta circunstancia, acordará la incorporación al procedimiento en curso de todo lo actuado en el anterior».

Aunque ofrece alguna duda, parece que los autos del concurso de acreedores, la quiebra o la suspensión de pagos anterior, cuando hubiesen concluido por inexistencia de bienes y derechos de deudor persona natural, deben incorporarse al nuevo concurso del mismo deudor, cuando se declare dentro de los cinco años siguientes de haberse clausurado el anterior, y tendrá la consideración de reapertura de éste. Serán competentes los nuevos Juzgados de lo Mercantil, quienes oficia-

20 Admisión, sustanciación y decisión de las cuestiones incidentales. «... 2. En la providencia sucintamente motivada en que se admita el planteamiento de la cuestión se resolverá si ha de considerarse de previo o de especial pronunciamiento, suspendiéndose, en el primer caso, el curso ordinario de las actuaciones. 3. Trasladado a las demás partes el escrito en que se plantee la cuestión, podrán contestar lo que estimen oportuno en el plazo de cinco días y, transcurrido este plazo, el tribunal citará a las partes a una comparecencia, que se celebrará conforme a lo dispuesto para las vistas de los juicios verbales. 4. Formuladas las alegaciones y practicada, en su caso, la prueba que en la misma vista se admita, si la cuestión fuere de previo pronunciamiento, se dictará, en el plazo de diez días, auto resolviendo la cuestión y disponiendo lo que sea procedente respecto a la continuación del proceso. Si la cuestión fuere de especial pronunciamiento, será resuelta, con la debida separación, en la sentencia definitiva. 5. Cuando la cuestión se resuelva por medio de auto, si éste acordare poner fin al proceso, cabrá recurso de apelación, y si decidiere su continuación, no cabrá recurso alguno, sin perjuicio de que la parte perjudicada pueda impugnar la resolución al apelar la sentencia definitiva». 
rán a los Juzgados de Primera Instancia correspondientes para dicha acumulación.

«2. La reapertura del concurso de deudor persona jurídica concluido por inexistencia de bienes y derechos será declarada por el mismo juzgado que conoció de éste, se tramitará en el mismo procedimiento y se limitará a la fase de liquidación de los bienes y derechos aparecidos con posterioridad. A dicha reapertura se le dará la publicidad prevista en los artículos 23 y 24».

De nuevo anticipo algunas dudas, pero me parece lo más seguro que la reapertura del anterior procedimiento concursal de persona jurídica (suspensión de pagos o quiebra, generalmente), con causa en que hubiesen aparecido nuevos bienes o derechos, será competencia del mismo Juzgado de Primera Instancia que conoció del anterior juicio universal, a cuyo auto de reapertura se dará la publicidad meramente informativa o «publicidad-noticia» (art. 23), así como la correspondiente constancia registral en los registros jurídicos de personas y de bienes, en este supuesto en el Registro Mercantil u otros registros públicos y en el Registro de la Propiedad, etc. (art. 24), y que abrirá la fase de liquidación, a la que será de aplicación lo dispuesto en los arts. 145 a 153 de la nueva Ley Concursal. Será preciso que el Juez nombre órgano auxiliar, es decir, depositario en el concurso de acreedores; depositario y comisario en la quiebra; o interventores en la suspensión de pagos, con arreglo a la legislación derogada, aunque no resultaría forzada la interpretación que considerase procedente el nombramiento de administradores concursales $e x$ art. 27 de la nueva Ley, previa declaración de procedimiento ordinario o abreviado.

La tramitación procesal de la fase de liquidación de los bienes y derechos de la persona jurídica concursada, quebrada o suspensa, aparecidos con posterioridad al archivo del respectivo procedimiento, tendrá lugar conforme a lo previsto en la Sección 2. ${ }^{a}$ Capítulo II del Título V de la citada Ley Concursal. La apertura de la fase de liquidación tiene determinados efectos, sobre el deudor, según el art. 145, entre otros: suspensión de sus facultades de administración y disposición; si fuese persona jurídica, que es el caso, su disolución y cese de administradores o liquidadores, que serán sustituidos por la administración concursal, es decir, por el anteriormente mencionado órgano auxiliar; y, sobre los créditos concursales, según el art. 146, el vencimiento anticipado y conversión en dinero de aquéllos que consistan en otras prestaciones. Esta referencia a créditos concursales, recuerda la necesidad de que la administración concursal actualice la lista de acreedores, según dispone el art. 180, que comentaré en el siguiente epígrafe. 
Según el art. 147, durante la fase de liquidación seguirán aplicándose las normas contenidas en el Título III de esta Ley, que regula los efectos de la declaración de concurso, es decir, deberán respetarse los arts. 40 a 73, en cuanto no se opongan a las específicas de la fase de liquidación (capítulo II, del título V), particularmente las dedicadas a las operaciones de liquidación (arts. 148 a 153). Precisamente, el citado art. 148 obliga a la administración concursal a presentar al Juez un plan para la realización de los bienes y derechos integrados en la masa activa (plan de liquidación) o la observancia de reglas legales supletorias ex art. 149, previo inventario de la masa activa, según previene el citado art. 180, para dedicar su producto al pago de los créditos contra la masa y de los concursales, previo reconocimiento y graduación, ¿conforme a la normativa del procedimiento que se trate? No me parece acertado y considero que deberán aplicarse los arts. 85 a 94 de la Ley Concursal. El pago a los acreedores, me parece, se hará conforme a lo dispuesto en los arts. 154 a 162, pues se integra en la fase de liquidación.

En la quita y espera, el art. 1.140 de la anterior LEC reconoce derecho de abstención a determinadas categorías de créditos, aunque sobre privilegios, en general, puede aceptarse lo dispuesto para el concurso de acreedores, en cuyo procedimiento la graduación de créditos tiene lugar en junta de los acreedores, a la que darán cuenta los síndicos de cuatro estados, según el art. 1.268 de dicha LEC, que comprenderán: $1 .^{\circ}$ Los acreedores por trabajo personal y alimentos; $2 .^{\circ}$ Los acreedores hipotecarios y pignoraticios; $3 .^{\circ}$ Los acreedores por escritura pública; $4 .^{\circ}$ Los acreedores comunes. Estos estados de acreedores deben formarse de conformidad con lo dispuesto en los arts. 1.921 a 1.925 del Código Civil.

En la suspensión de pagos, la aprobación del convenio exige la constitución de una masa de acreedores (créditos concurrentes), a los cuales se les califica jurídicamente de forma especial, en función de la relación de créditos preparada por la comisión interventora y, finalmente, aprobada por el juez: lista definitiva de acreedores (art. 12 de la Ley especial), aunque no tiene lugar la graduación de créditos, propiamente dicha, sino la formación de dos grupos de acreedores: a) Acreedores con derecho de abstención; b) Resto de acreedores. El artículo 15 de la citada Ley señala: "Los acreedores singularmente privilegiados, los privilegiados y los hipotecarios, comprendidos en los números $1 .^{\circ}, 2 .^{\circ}$ y $3 .^{\circ}$ del artículo 913 del Código de Comercio, podrán abstenerse de concurrir a la Junta, pero si concurrieran quedarán obligados como los demás acreedores». El art. 913.3..$^{\circ}$ incluye los privilegiados por derecho común, es decir, los créditos vinculados con aquéllos menciona- 
dos en los artículos 1.922, 1.923 y 1.924 del Código civil. El art. 22 concede el mismo derecho de abstención a los acreedores que invoquen los derechos reconocidos en los arts. 908 a 910 del C. de C., es decir, a los mal llamados acreedores de dominio.

En la quiebra, la graduación de los créditos reconocidos tiene lugar en junta de acreedores, señalando la naturaleza y lugar que debe ocupar cada uno, para que sean pagados con la preferencia que les corresponda. El Código de Comercio vigente dedica parte de la Sección Quinta, concretamente los arts. 912 al 919, a la graduación y pago de créditos. Ante la falta de un texto refundido y único, regulador de la preferencia y prelación de créditos de todas clases, puede decirse que en el Código civil se encuentran las disposiciones generales que han de mencionarse a la hora de dar alguna luz sobre la graduación de créditos en las quiebras, para la aplicación de lo establecido en el mencionado art. 913.3. ${ }^{\circ}$ del Código Mercantil. En dicho contexto, los referidos artículos 1.922, 1.923 y 1.924 del Código Civil.

Conviene recordar, en todos los supuestos de apertura de la fase de liquidación, que el concurso de acreedores se calificará como fortuito o como culpable, en la sección sexta del procedimiento, según dispone el art. 164, aunque el tono imperativo del art. 179.2, «La reapertura... se limitará a la fase de liquidación de los bienes y derechos aparecidos con posterioridad», permite interpretar que la calificación de la conducta del deudor está vedada. Sin embargo, me inclino por la procedencia de tramitar también la sección sexta, para evitar quedasen impunes actuaciones irregulares de los administradores sociales de la persona jurídica deudora, desde la clausura hasta la reapertura, cualquiera que hubiese sido la calificación anterior, en su caso, y aplicando los arts. 164 a 173 de la Ley Concursal, en la medida que no prevalezca, en dicha materia calificadora, el aludido principio de irretroactividad de las normas legales que bien pudieran considerarse sancionadoras. Si así fuese, la calificación de la conducta del deudor, durante el periodo transcurrido desde la clausura hasta la reapertura, se hará conforme a las disposiciones citadas de la anterior legislación concursal, salvo que se valore más acertado el criterio expuesto favorable a la observancia de los preceptos vigentes, particularmente en el caso de que la conducta a calificar corresponda a un periodo posterior al uno de septiembre de dos mil cuatro.

\subsubsection{Inventario y lista de acreedores}

El art. 180 dispone: «1. Los textos definitivos del inventario y de la lista de acreedores formados en el procedimiento anterior habrán de actualizarse por la administración concursal en el plazo de dos meses 
a partir de la incorporación de aquellas actuaciones al nuevo concurso. La actualización se limitará, en cuanto al inventario, a suprimir de la relación los bienes y derechos que hubiesen salido del patrimonio del deudor, a corregir la valoración de los subsistentes y a incorporar $y$ valorar los que hubiesen aparecido con posterioridad; en cuanto a la lista de acreedores, a indicar la cuantía actual y demás modificaciones acaecidas respecto de los créditos subsistentes y a incorporar a la relación los acreedores posteriores».

Creo que es un texto claro, para actualizar la información sobre masa activa y pasiva en la declaración de concurso de deudor persona natural, dentro de los cinco años siguientes a la conclusión de otro anterior por inexistencia de masa activa (art. 179.1), así como en la reapertura del concurso de persona jurídica regulado en el anteriormente referido art. 179.2, aunque no encuentro explicación a que dicha actualización, en cuanto al inventario, consista en suprimir de la relación los bienes y derechos que hubiesen salido del patrimonio del deudor y a corregir la valoración de los subsistentes, cuando la clausura del anterior concurso fue causada por inexistencia de masa activa, es decir, desde su conclusión no han podido salir ni subsistir bienes o derechos que no existían entonces, a no ser que hubiesen sido ocultados (alzamiento).

Sin embargo, cuando se trate de la declaración de nuevo concurso de persona natural, dentro de los cinco años siguientes a la conclusión de quita y espera, suspensión de pagos, concurso de acreedores o quiebra, por inexistencia de masa activa (art. 179.1), o de la reapertura de concurso de acreedores, quiebra o suspensión de pagos de persona jurídica, recuerdo que en este último procedimiento no se menciona el inventario como documento contable y deberá ponerse en relación con el activo del balance ex art. 8 de la Ley especial, concretamente con la masa activa determinada por el juez respecto de la verificada por la intervención. En el concurso de acreedores, la masa activa la forman los síndicos (art. 1.228 de la anterior LEC), y en la quiebra la sindicatura forma el inventario del haber (bienes y derechos) ex art. 1.355 de la anterior LEC, en relación con los arts. 1.079 a 1.081 del primer C. de Comercio. Lo expuesto queda como derecho histórico y en el transitorio habrá de actuarse según se expone en el apartado siguiente.

Respecto de la lista de acreedores, deberán actualizarse los créditos reconocidos en el concurso de acreedores (art. 1.262 de la anterior LEC), así como en la quiebra (arts. 1.380 y 1.381 de la misma LEC), al igual que en la suspensión de pagos (art. 12 de la Ley especial), de conformidad con lo dispuesto en el apartado siguiente. 
«2. La actualización se realizará y aprobará de conformidad con lo dispuesto en los capítulos II y III del título IV de esta Ley. La publicidad del nuevo informe de la administración concursal y de los documentos actualizados y la impugnación de éstos se regirán por lo dispuesto en el capítulo IV del título IV, pero el juez rechazará de oficio y sin ulterior recurso aquellas pretensiones que no se refieran estrictamente a las cuestiones objeto de actualización».

Los capítulos citados se refieren a la determinación de las masas activa (arts. 76 a 83) y pasiva (arts. 84 a 94), que comprende la calificación de créditos, referidas a la fecha del auto de reapertura, su publicidad e impugnación (arts. 95 a 97).

El inventario de la masa activa de persona natural no casada y de persona jurídica, según el art. 82, consistirá en una relación con los siguientes datos: 1) Descripción de bienes y derechos; 2) Naturaleza; 3) Características; 4) Lugar en que se encuentran; 5) Datos de identificación registral; 6) Gravámenes, trabas y cargas; y, 7) Valoración. Cuando el deudor fuese persona casada, dicho inventario incluirá, además, la relación de los bienes y derechos gananciales o comunes, con expresa indicación de su carácter. A dicho inventario se añadirán dos relaciones, a saber: a) Una, con los litigios cuyo resultado pueda afectar a los bienes y derechos incluidos en el mismo; b) Y otra, con las acciones que debieran promoverse para la reintegración de la masa activa (art. 71). En estas dos relaciones se informará sobre viabilidad, riesgos, costes y posibilidades de financiación de las correspondientes actuaciones judiciales. Además, cuando la administración concursal haya acudido a expertos independientes para la valoración de los bienes y derechos inventariados, unirán al inventario los informes emitidos por tales expertos y el detalle de los honorarios devengados con cargo a la masa, según dispone el art. 83.2.

La lista de acreedores comprenderá dos relaciones, a saber:

A) Relación de créditos incluidos, ordenada en el apartado 2 del art. 94, se presentará con múltiples columnas, a saber: 1) Identidad; 2) Causa; 3) Principal comunicado; 4) Intereses y sanciones comunicados; 5) Principal reconocido; 6) Intereses y sanciones reconocidos; 7) Suma, en su caso; 8) Fechas de origen; 9) Fechas de vencimiento; 10) Garantías personales; 11) Garantías reales; 12) Calificación jurídica del principal y de los intereses o sanciones; 13) Carácter de litigioso del principal o de los intereses (sin cuantía); 14) Condicionales; 15) Pendiente de excusión; 16) Falta de comunicación oportuna; u otras, si se incluye la dirección de los acreedores, aunque no se menciona, salvo que se considere implícita en la identidad, así como si se 
incorpora una columna final, para observaciones o para referenciar anexos, que resultarán convenientes para dejar constancia de datos complementarios de los créditos verificados. Si el deudor fuese persona casada, en régimen de gananciales o de comunidad de bienes (art. 86.3), se presentarán dos relaciones de acreedores separadas, es decir, los créditos que sólo puedan hacerse efectivos sobre su patrimonio privado y los que puedan hacerse efectivos sobre el patrimonio común.

B) Relación de créditos excluidos (apartado 3 del art. 94), que expresará la identidad de cada uno de ellos y los motivos de la exclusión, es decir, no presentará importes, al parecer, sólo la identidad del acreedor y la causa de su exclusión, aunque considero una omisión cuestionable, pues debiera figurar el importe declarado por el deudor o reclamado por el acreedor.

El apartado 4 del art. 94 exige otra relación separada, sobre el detalle y cuantía de los créditos contra la masa devengados y pendientes de pago, que en el Derecho derogado son ajenas al proceso concursal y ostentaban derecho de ejecución separada, y que resultará indispensable con vistas a la liquidación en curso.

\subsubsection{APERTURA DE CONCURSO POR INCUMPLIMIENTO DE CONVENIO}

El número 2 de la referida disposición transitoria primera dispone que la resolución judicial que declare el incumplimiento de un convenio aprobado en cualquiera de los procedimientos concursales derogados, a los que se ha hecho mención [quita y espera (art. 1.155 LEC 1881), suspensión de pagos (art. 17 LSP), concurso de acreedores (art. 1.919 CC) y quiebra (art. 906 C. de C.)], y gane firmeza después de la entrada en vigor de esta Ley, producirá la apertura de oficio del concurso del deudor a los solos efectos de tramitar la fase de liquidación regulada en ella (arts. 144 a 153 de la Ley Concursal). Según la Magistrada Hernández Rodríguez ${ }^{21}$ : «... en estos casos, en lugar de continuar con la tramitación establecida en la legislación anterior..., se abre el concurso del deudor, a los solos efectos de liquidación, es decir, con una tramitación muy limitada, sin fase común... no se trata de un concurso completo, en el sentido de la Ley Concursal, sino de la integración de la legislación concursal anterior con la nueva...».

21 Hernández RodríGuEZ, María del Mar «Algunos problemas del régimen transitorio de los procedimientos concursales iniciados al amparo de la legislación anterior», pág. 299. Anuario de Derecho concursal, 4/2005, Editorial Aranzadi, S. A. 
Conocerá de este concurso el mismo juzgado que hubiere tramitado el precedente procedimiento concursal, es decir, se sustrae a la competencia de los Juzgados de lo Mercantil y mantendrá la competencia el mismo Juzgado de Primera Instancia que conoció del procedimiento anterior, cuyo convenio ha declarado incumplido. Puntualiza la Magistrada Hernández Rodríguez ${ }^{22}$ : «La opción del legislador, en realidad, no supone una excepción a las normas sobre competencia objetiva, que impide el conocimiento de la materia concursal por parte de los juzgados de primera instancia, sino precisamente el mantenimiento en este aspecto del principio de irretroactividad, al mantener la competencia del juez de primera instancia a pesar el nuevo cauce procesal a seguir».

El auto de declaración de concurso, por incumplimiento de convenio en suspensión de pagos o quiebra (también en quita y espera o en concurso de acreedores, inhabituales), además de la apertura de la fase de liquidación, tendrá necesariamente otros pronunciamientos: a) Nombramiento de administradores concursales; b) El requerimiento al deudor para que presente, en el plazo de 10 días a contar desde la notificación del auto, los documentos enumerados en el artículo 6; c) En su caso, las medidas cautelares que el juez considere necesarias para asegurar la integridad, la conservación o la administración del patrimonio del deudor hasta que los administradores concursales acepten el cargo; d) El llamamiento a los acreedores para que pongan en conocimiento de la administración concursal la existencia de sus créditos, en el plazo de un mes a contar desde la última de las publicaciones acordadas en el auto, dentro de las que con carácter obligatorio establece el apartado 1 del artículo 23; e) La publicidad que haya de darse a la declaración de concurso; f) En su caso, la decisión sobre la procedencia de aplicar el procedimiento especialmente simplificado a que se refiere el capítulo II del título VIII de esta Ley; g) Se ordenará la formación de las secciones segunda, tercera y cuarta.

En todos los supuestos de apertura de la fase de liquidación procederá la formación de la sección de calificación (art. 163.1.2..$^{\circ}$ ), aunque se hubiese tramitado en el procedimiento anterior y que no habrá tenido lugar en la quita y espera. Sin embargo, no debo desconsiderar la prevención «producirá la apertura de oficio del concurso del deudor a los solos efectos de tramitar la fase de liquidación regulada en ella», pero me inclino por considerar procedente la tramitación de la sección sexta de calificación, como he comentado en el epígrafe anterior sobre reapertura del procedimiento, para valorar la conducta del deudor.

22 Op. cit., pág. 299. 
Recuerdo algunos efectos sobre el deudor y los acreedores, que se contemplan en el art. 145 (suspensión de las facultades de administración y, en su caso, extinción del derecho a alimentos o disolución societaria y cese de administradores o liquidadores) y 146 (vencimiento anticipado de los créditos), respectivamente, así como el nombramiento del órgano auxiliar del Juzgado ex art. 27, previa decisión judicial sobre su tramitación ordinaria o abreviada (arts. 190 y 191) y la publicidad correspondiente, así como la necesaria actualización de la masa activa y pasiva (arts. 76 a 94), en los términos expuestos en el epígrafe anterior.

La Magistrada Hernández Rodríguez ${ }^{23}$ ofrece su autorizada opinión sobre algunos de los pasajes anteriores y contempla otros escenarios posibles:

«1. El convenio incumplido con auto de declaración de incumplimiento. Este supuesto no plantea ningún problema puesto que es el específicamente referido en la Ley. Por lo tanto, si se declara el incumplimiento del convenio, el juez que dicta esta resolución, a continuación, de oficio, deberá declarar el concurso del deudor, sin necesidad de argumentar sobre su situación de insolvencia, y a los solos efectos de la tramitación de la fase de liquidación. No obstante, nada impide que algún legitimado solicite la declaración de concurso ante el Juzgado de Primera Instancia competente. En cambio, si en este caso algún legitimado instase la declaración de concurso ante el Juzgado de lo Mercantil, la resolución procedente sería la de inadmisión de la solicitud.

2. El convenio incumplido sin resolución que lo declare. Este problema se plantea en aquellos supuestos en que, transcurrido el plazo en que debió ser cumplido el convenio, no existe resolución judicial al respecto y es solicitada la declaración de concurso. La aplicación de la disposición transitoria analizada exige la previa resolución declarando el incumplimiento del convenio, pero se plantea la situación de que ningún acreedor haya instado tal pronunciamiento y el deudor, ante su situación de insolvencia, solicite la declaración de concurso. En este caso, como no existe resolución judicial, no es posible acudir a la vía prevista expresamente por la disposición transitoria. La referida disposición únicamente da respuesta al supuesto perfecto de que el incumplimiento del convenio sea declarado judicialmente y deja en cambio sin prever específicamente lo que sucede en aquellos casos en que se ha incumplido por no satisfacer las deudas en los términos acorda-

23 Op. cit., págs. 306-308. 
dos pero no exista resolución judicial al efecto. El problema se plantea en el supuesto de que se presente una solicitud de concurso ante el Juzgado de lo Mercantil. De tratarse de una solicitud de concurso voluntario y presentarse completa la documentación exigida (art. 6 LC), lo que es en todo caso preciso para la admisión a trámite de la solicitud, o con mayor precisión, para su no inadmisión, en tanto que legalmente no se prevé una resolución admitiendo a tramite, de ella se extraerá el incumplimiento del convenio, con lo que será posible traer a colación la disposición transitoria y abstenerse de conocer por falta de competencia objetiva, ante la situación de incumplimiento, debiendo las partes acudir al órgano de primera instancia competente para recabar una resolución que declare el incumplimiento. En cambio, en aquellos supuestos en que, a pesar de haberse aportado toda la documentación exigida, ésta estuviera incompleta y la contabilidad se hubiera llevado incorrectamente, de modo que no sea posible conocer en esa fase de admisión tan breve la previa existencia de un convenio incumplido, y en los supuestos de solicitud de concurso necesario en el que no existe oposición o habiéndose producido ésta, de la documentación aportada no se extrae el incumplimiento de un convenio, la solución será diferente: si se acredita la situación de insolvencia, se declarará el concurso con la consecuencia de que una vez que se tenga conocimiento en la fase común de la existencia del convenio, deberá concluirse el concurso, por aplicación de la disposición transitoria 1. ${ }^{a}$, y tendrán que acudir las partes al Juez que conoció del procedimiento anterior, o de postularse la solución antes aludida que residencia la cuestión en reglas de competencia objetiva, deberá abstenerse de conocer el juez. que está tramitando el concurso apreciando de oficio su falta de competencia objetiva, indicando la competencia del Juzgado de Primera Instancia correspondiente, con la fatal consecuencia de declaración de nulidad de todo lo actuado, que sin duda habrá representado importantes costes (art. 48 LECiv). No obstante, la problemática se mantiene en los supuestos en los que los acreedores, a pesar de que exista un incumplimiento del convenio, por diferentes motivos, no instan la declaración judicial de incumplimiento. Ha de partirse de que con carácter general únicamente se otorga la iniciativa para instar el incumplimiento a los acreedores (arts. 17-IV LSP y 906 CCom), con lo que se plantea la situación del deudor que desea la declaración de incumplimiento para poder abrir posteriormente un concurso. En este caso la solución no puede pasar por entender que no resulta de aplicación la disposición transitoria primera por la falta de declaración de incumplimiento y el deudor puede instar la declaración de concurso ante el Juzgado de lo Mercantil. Téngase en cuenta que, de declararse el concurso en este 
supuesto, en algún momento, si quiera tácitamente, el juez del concurso tendría que pronunciarse sobre el incumplimiento del convenio, decisión para la que no resulta competente. Por ello, la vía posible parece ser la necesidad de que sea el propio deudor el que provoque la declaración judicial de incumplimiento, cuando se dé esta situación, no se haya instado esta declaración por parte de los acreedores y al deudor le interese la liquidación, entendiendo que sí se encuentra legitimado el deudor para solicitar tal pronunciamiento.

3. El convenio en fase de cumplimiento. El problema es similar en resultados al anterior, el supuesto en que aprobado un convenio, cuando éste se encuentra aún en fase de cumplimiento, algún legitimado interesa la declaración de concurso ante el Juzgado de lo Mercantil (lo que ya ha sucedido en algunos tribunales). En este caso, si de la documentación aportada con la solicitud de concurso o en la vista tras oposición (lo que será más fácil en el supuesto de concurso voluntario), al igual que en el supuesto anterior, se extrae la vigencia de un convenio, debe inadmitirse a trámite la solicitud de concurso. En el supuesto de que no se tuviese ese conocimiento en el momento de solicitar el concurso y se declarase éste, desde que constase en autos su vigencia, deberá terminarse en ese momento el concurso por estar otro procedimiento abierto sobre la misma materia con clara litispendencia entre ambos o, según la segunda postura, dictarse un auto, absteniéndose el juez del concurso de conocer y dando lugar a la nulidad de todo lo actuado (art. 48 LECiv). Esto incluso en el supuesto de que la solicitud la hubiese presentado un acreedor no afectado por el convenio ${ }^{24} \gg$.

${ }^{24}$ Lo que no podrá hacerse es ampararse en esa nueva solicitud para obtener otro convenio que sustituya al anterior, bien durante su vigencia, bien ante el incumplimiento del mismo. Dejando a un lado las teorías sobre la naturaleza jurídica del convenio, la Ley Concursal opta claramente por su consideración como un negocio jurídico en el que la autonomía de la voluntad goza de gran libertad (aunque en la práctica se encuentra sumamente limitada). Sin embargo, es un negocio jurídico en el que no existe posibilidad de novación una vez aprobado (aprobación que en todo caso es judicial). Si se produce un incumplimiento o varían las circunstancias a lo largo de su vigencia, no es posible la aprobación de un nuevo convenio que sustituya al anterior puesto que la consecuencia se encuentra legalmente establecida, sin posibilidad de excepción, la apertura de la liquidación. Esto implica, que la única posibilidad de burlar la aplicación de esta regla que impone la liquidación viene dada por la inactividad de las partes denunciando esta falta de cumplimiento (que no puede ser declarada de oficio por el juez). Esto es así, incluso en el supuesto de que sean nuevos algunos de los acreedores que no resultaron afectados por el anterior convenio o de acreedores que según la legislación anterior quedaban fuera de él, puesto que en los convenios han de tenerse en cuenta las posibilidades de cumplimiento de las deudas no sólo de los acreedores a quienes afecten, sino también de terceros y de las futuras. 


\subsubsection{CONVENIO EN LA QUIEBRA}

Dispone el número 3 de la citada Disposición Transitoria Primera que en la quiebra de cualquier clase de sociedades no podrá aprobarse ninguna proposición de convenio antes de que haya concluido el trámite de reconocimiento de créditos (arts. 1.380 y 1.381 de la anterior LEC). No será de aplicación, por tanto, el art. $929^{25}$ del C. de C., que se remite a los arts. 930 y siguientes del mismo Código Mercantil, que permitía la tramitación de convenio anticipado en la quiebra de las compañías, antes de la celebración de la Junta de reconocimiento de créditos e incluso con anterioridad al nombramiento de la sindicatura, es decir, durante la actuación del depositario (STS de 8.06.188026 y SAT de Barcelona de 30.06.198727).

El referido art. 929 del Código de Comercio determina la facultad de las compañías (sociedades anónimas y de responsabilidad limitada) de presentar a los acreedores las proposiciones de convenio que estimen oportunas, en cualquier estado de la quiebra, y también a su tramitación acomodada a lo dispuesto en los artículos 932 a 937 del citado Código Mercantil. Este último artículo (937) dispone: "Aprobado el convenio sin oposición, o desestimada ésta por sentencia firme, será obligatorio para la compañía o empresa deudora y para todos los acreedores cuyos créditos daten de época anterior a la suspensión de pagos, si hubieren sido citados en forma legal, o si, habiéndoseles notificado el convenio, no hubieren reclamado contra él en los términos

25 «Las compañías estarán representadas durante la quiebra según hubieren previsto para este caso los estatutos, y en su defecto, por el Consejo de administración; y podrán en cualquier estado de la misma presentar a los acreedores las proposiciones de convenio que estimen oportunas, las cuales deberán resolverse con arreglo a lo que se dispone en la Sección siguiente»

26 «...Que también son infundados los motivos de casación en que se pretende el imposible de que en la pieza de calificación de una quiebra se oiga a síndicos que no existen, ni deben existir, puesto que realizado el convenio no había para qué proceder a su nombramiento, y bastaba la representación fiscal para el único interés restante de la causa pública».

27 «Modificado el artículo 1.147 del Código de Comercio de 1829 por la Ley de 30 de julio de 1878, en el sentido de no autorizarse la celebración de convenios entre el quebrado y sus acreedores sin que hubiere terminado el examen y reconocimiento de los créditos y haberse hecho la calificación de la quiebra, con independencia del acierto o no del legislador en las razones por las que se excluyó de dicha regla a las sociedades anónimas, es lo cierto que, de forma expresa a las mismas se refiere en la Exposición de Motivos de la propia Ley que establece la excepción al señalar el artículo 929 del Código de Comercio que podrán «en cualquier estado de la misma presentar a los acreedores las proposiciones de convenio que estimen oportunas». Consecuentemente con ello no queda sujeta en el tiempo la proposición del convenio a la aprehensión física de los bienes y documentos de la sociedad quebrada». 
prevenidos en la Ley de Enjuiciamiento Civil». Interpreto que obliga a todos los acreedores, sin excepción alguna, es decir, que no excluye a los acreedores con derecho de abstención, como ocurre en el caso del convenio regulado en la Sección Cuarta (arts. 898 a 907), pues el art. 904 se remite al art. 900, y éste confiere la facultad de abstenerse a los acreedores singularmente privilegiados, los privilegiados y los hipotecarios. Así parece desprenderse de la SAT de Barcelona, de 30.06.198728, y su tramitación se resume por Ramírez ${ }^{29}$.

\subsubsection{Propuestas de Convenio}

El número 4 de la reiterada Disposición Transitoria Primera dispone que las proposiciones de convenio que se formulen con posterioridad a la entrada en vigor de la nueva Ley Concursal, en cualquiera de los procedimientos derogados, deberán cumplir los requisitos establecidos en los artículos 99 y 100 de la citada Ley.

Toda propuesta de convenio, que podrá contener distintas alternativas, se formulará por escrito y firmada por el deudor o, en su caso, por todos los acreedores proponentes, o por sus respectivos representantes con poder suficiente. De las propuestas presentadas se dará traslado a las partes personadas. Cuando la propuesta contuviera compromisos de pago a cargo de terceros para prestar garantías o financiación, realizar pagos o asumir cualquier otra obligación, deberá ir firmada, además, por los compromitentes o sus representantes con poder suficiente (art. 99).

Las propuestas de convenio no podrán ofrecer una quita que exceda de la mitad de los créditos ordinarios, ni espera superior a cinco años, excepto en empresas con especial trascendencia para la economía (nacional, autonómica, provincial o local), cuando de propuesta ordinaria de convenio se tratase (art. 100.1), es decir, si no fuese propuesta anticipada, pues en ésta la excepción a los indicados límites se admitirá cuando el plan de viabilidad contemple expresamente su superación y el Juez lo autorice (art. 104.2). Además, dichas propuestas podrán contener proposiciones alternativas, incluidas las ofertas de conversión de créditos en acciones, participaciones o cuotas sociales (arts. 156 TRLSA y 74 LSRL), o en créditos participativos (art. 20 Real Decreto 7/1996, de 7 de junio). Conviene llamar la atención sobre la limitación en la espera a cinco años, que parece afectará a las citadas proposiciones alternativas $y$, en concreto, a la conversión de créditos en préstamos parti-

28 Baró Casals, Antonio y Pedreño Maestre, Francisco, Derecho Concursal. Tomo II. La Quiebra, Cedecs, Barcelona, 1999, pág. 701.

29 Ramírez, José A., La quiebra. Barcelona, Bosch, tomo III, págs. 626-628. 
cipativos o en obligaciones convertibles en acciones (arts. 292-294 TRLSA). También podrán incluirse en la propuesta de convenio proposiciones de enajenación, bien del conjunto de bienes y derechos del concursado afectos a su actividad empresarial o profesional o de determinadas unidades productivas a favor de una persona natural o jurídica determinada. Las proposiciones incluirán necesariamente la asunción por el adquirente de la continuidad de la actividad empresarial o profesional propia de las unidades productivas a las que afecte y del pago de los créditos de los acreedores, en los términos expresados en la propuesta de convenio. En estos casos, deberán ser oídos los representantes legales de los trabajadores (art. 100.2). La propuesta de convenio no puede consistir en datio pro soluto o pro solvendo, ni en la liquidación global del patrimonio (masa activa), etc., sin perjuicio de la posibilidad de fusión o escisión (arts. 233 a 259 TRLSA y 94 LSRL) de la persona jurídica concursada, según el art. 100.3.

En la tramitación y aprobación de dichas propuestas de convenio, conforme al procedimiento que en cada caso corresponda, será de aplicación lo establecido en el artículo $103^{30}$ y en el apartado 3 del artículo $118^{31}$, así como en el párrafo segundo del apartado 4 del artículo $121^{32}$ de la referida Ley Concursal, debiendo entenderse que el plazo para la presentación de adhesiones escritas comprende desde la presentación de la propuesta de convenio hasta el momento de formación de la lista de asistentes a la junta en que será sometida a aprobación, salvo que se trate de suspensiones de pagos o quiebras de sociedades en las que el convenio pueda aprobarse sin celebración de junta, es decir, mediante trámite escrito, en cuyo caso ese plazo será el señalado para presentar

30 Artículo 103. Adhesiones a la propuesta de convenio. «1. Los acreedores podrán adherirse a cualquier propuesta de convenio en los plazos y con los efectos establecidos en esta Ley. 2. La adhesión será pura y simple, sin introducir modificación ni condicionamiento alguno. En otro caso, se tendrá al acreedor por no adherido. 3. La adhesión expresará la cuantía del crédito o de los créditos de que fuera titular el acreedor, así como su clase, y habrá de efectuarse mediante comparecencia ante el secretario del juzgado en el que se tramite el concurso, o mediante instrumento público. 4. La adhesión a estos convenios por parte de las Administraciones y organismos públicos se hará respetando las normas legales y reglamentarlas especiales que las regulan».

$31 \ll 3$. Los acreedores firmantes de algunas de las propuestas y los adheridos en tiempo y forma a cualquiera de ellas que no asistan a la junta se tendrán por presentes a efectos del quórum de constitución».

32 «4. Concluido el debate, el presidente someterá la propuesta a votación nominal y por llamamiento de los acreedores asistentes con derecho a voto. Los acreedores asistentes podrán emitir el voto en el sentido que estimen conveniente, aunque hubieren firmado la propuesta o se hubieren adherido a ella. Se computarán como votos favorables a la correspondiente propuesta de convenio los de los acreedores firmantes y los de los adheridos que no asistiendo a la junta hayan sido tenidos por presentes». 
adhesiones en el correspondiente procedimiento. Se contempla, por tanto, el procedimiento escrito del convenio en la suspensión de pagos (arts. $18^{33}$ y 19 de la Ley especial de 1922) y en la quiebra (arts. 932 $2^{34}$, $934^{35}$ y $935^{36}$ del C. de C.).

En la suspensión de pagos, el convenio parte de la proposición presentada con su solicitud por el deudor para pago de sus débitos (art. 2.4. ${ }^{\circ}$ de la LSP) y puede ser modificado por los acreedores con el asentimiento del suspenso. Se cuestiona por la doctrina si el deudor puede modificar su propuesta inicial de convenio, inclinándome por la respuesta afirmativa. Así parece desprenderse de lo ordenado en el art. 2.5. ${ }^{\circ}$ in fine de la LSP, para las sociedades anónimas, cuando establece que en el acuerdo de la junta general de accionistas se indicarán las personas... que habrán de ostentar la plena representación de la sociedad... con facultad para modificar la proposición de convenio formulada... No debe haber causa de discriminación para deudores personas naturales y jurídicas. En la junta de acreedores, convocada para deliberar sobre la aprobación del convenio, el juez abre a discusión la proposición de convenio formulada por el deudor, la cual podrá ser libremente mo-

33 «En el auto en que se estime la solicitud se concederá al suspenso un plazo prudencial, que no podrá ser inferior a un mes ni superior a cuatro, para que presente al Juzgado la proposición de convenio con la adhesión de los acreedores obtenida en forma auténtica».

${ }^{34}$ «La compañía o empresa que se presentare en estado de suspensión de pagos, solicitando convenio con sus acreedores, deberá acompañar a su solicitud el balance de su activo y pasivo. Para los efectos relativos al convenio, se dividirán los acreedores en tres grupos: el primero comprenderá los créditos de trabajo personal y los procedentes de expropiaciones, obras y material; el segundo, los de las obligaciones hipotecarias emitidas por el capital que las mismas representen, y por los cupones y amortización vencidos y no pagados, computándose los cupones y amortización por su valor total, y las obligaciones según el tipo de emisión, dividiéndose este grupo en tantas secciones cuantas hubieren sido las emisiones de obligaciones hipotecarias; y el tercero, todos los demás créditos, cualquiera que sea su naturaleza y orden de prelación entre sí y con relación a los grupos anteriores».

35 «3. ${ }^{\circ}$ Impondrá a las compañías y empresas el deber de presentar al Juez o Tribunal, dentro del término de cuatro meses, una proposición de convenio para el pago de los acreedores, aprobada previamente en junta ordinaria o extraordinaria por los accionistas, si la compañía o empresa deudora estuviere constituida por acciones».

36 «El convenio quedará aprobado por los acreedores si le aceptan los que representen tres quintas partes de cada uno de los grupos o secciones señalados en el artículo 932. Se entenderá igualmente aprobado por los acreedores si no habiendo concurrido, dentro del primer plazo señalado al efecto, número bastante para formar la mayoría de que antes se trata, lo aceptaren en una segunda convocatoria acreedores que representaren los dos quintos del total de cada uno de los dos primeros grupos y de sus secciones, siempre que no hubiese oposición que exceda de otros dos quintos de cualquiera de dichos grupos o secciones, o del total pasivo». 
dificada por los acreedores, con el consentimiento de aquél, y podrán hablar tres acreedores a favor del convenio propuesto y tres en contra (art. 14 de la Ley especial).

En la suspensión de pagos, cuando los acreedores exceden de doscientos el juez podrá acordar la suspensión de la junta (dejarla sin efecto o desconvocarla) y su sustitución por la tramitación escrita, a petición del deudor o de cualesquiera de los acreedores, cuya solicitud deberá ser presentada a partir de la fecha del auto en el que se acuerda la convocatoria de la junta y hasta ocho días antes del señalado para su celebración. En caso de que se formulase la solicitud, el juez oirá preceptivamente el informe de los interventores, que deberán evacuarlo en el término de tres días, y resolverá lo procedente (art. 18 de la Ley especial). Cuando se acuerde la tramitación escrita, el suspenso vendrá obligado a presentar al juzgado la proposición de convenio (la inicial u otra), con la adhesión del voto individual de los acreedores en forma auténtica, bien por comparecencia ante el secretario judicial o mediante acta notarial, que sumen la mayoría de tres cuartos exigible en los supuestos de insolvencia definitiva y cuando el convenio consista en una espera superior a tres años, dentro del plazo que le conceda el juez, que no podrá ser inferior a un mes ni superior a cuatro, con obligada prórroga de treinta días más, si en el primer plazo no se reuniera, y así se acreditase por el deudor. Si las adhesiones recibidas introdujeran modificaciones esenciales en la proposición del convenio, tanto durante el plazo del citado art. 18 como en el de prórroga del art. 19, ambos de la Ley especial, el juez oirá obligatoriamente sobre ellas (las modificaciones al convenio propuesto) el informe de los interventores, que deberán emitirlo en el improrrogable plazo de quince días, y dará vista al deudor para que preste o no su consentimiento. También este informe carece de orientación legal y, en la práctica, de contenido ilustrativo; los interventores acostumbran a destacar las modificaciones planteadas respecto de la propuesta inicial del deudor y a analizar posibles ventajas económicas para las partes que resultasen beneficiadas con los cambios introducidos. En el supuesto que el suspenso no dé su conformidad a las modificaciones en el convenio presentadas por los acreedores el juez sobreseerá el expediente.

En el procedimiento de quiebra de los empresarios individuales y compañías de responsabilidad ilimitada, una vez terminado el reconocimiento de créditos y hecha la calificación, el quebrado y sus acreedores podrán hacer los convenios que estimen oportunos, según el art. 1.390 de la LEC, que se remite al art. 1.304 de la LEC, el cual ordena: "Toda solicitud que haga el deudor o cualquiera de los acreedores para convocatoria a junta que tenga por objeto el convenio, deberá contener los 
requisitos siguientes, sin los cuales no será admitida: $1 .{ }^{\circ}$ Que se formulen con claridad y precisión las proposiciones del convenio. $2 .^{\circ}$ Que se acompañen tantas copias de ellas, impresas o manuscritas, cuantos sean los acreedores reconocidos. $3 .^{\circ}$ Que el que las haga se obligue a satisfacer los gastos a que dé lugar la convocatoria y celebración de la junta, aunque se defienda por pobre, asegurando el pago a satisfacción del Juez». No gozarán de este derecho al convenio los quebrados fraudulentos ni los que se fugaren durante el juicio de quiebra (art. 898 del vigente C. de C.). Este artículo modificó la redacción del art. 1.147 del primer Código de Comercio, al que se refiere el art. 1.389 de la LEC, que prohibía presentar proposiciones de convenio hasta terminado el examen y reconocimiento de créditos y hecha la calificación de quiebra. Con el texto actual, se permite al quebrado presentar sus proposiciones de convenio a los acreedores o aceptar las que éstos le presenten, sin esperar a que finalice el examen y reconocimiento de créditos, consecuentemente su graduación, ni la calificación de la quiebra. En este supuesto, el convenio no podrá concluir hasta después de terminadas aquellas operaciones, es decir, se podrán presentar las propuestas de convenio por el deudor o sus acreedores, pero el juzgado deferirá la convocatoria de la junta de acreedores para deliberación y votación hasta que hayan finalizado su tramitación las piezas cuarta y quinta. Son aplicables, a este respecto, los arts. 1.307 a 1.311 de la LEC, a los que remite el art. 1.391 de la LEC. Debe repararse en que se excluye la remisión al art. 1.306 de la LEC y, consecuentemente, permite interpretar que los administradores de las sociedades regulares colectivas y sociedades comanditarias podrán hacer las proposiciones de convenio y representar a estas compañías en la junta de acreedores correspondiente.

En la quiebra de otras sociedades mercantiles, no parece que haya obstáculo para acogerse a los mismos trámites sobre convenio, en junta de acreedores, a las sociedades mercantiles de responsabilidad limitada (sociedades anónimas y de responsabilidad limitada), una vez finalizadas las piezas tercera, cuarta y quinta. Sin embargo, los administradores de las compañías anónimas o quienes les representen según poder especial, y por extensión las de responsabilidad limitada, así como los liquidadores de las compañías disueltas, podrán presentar a los acreedores, en cualquier estado de la quiebra, las proposiciones de convenio que estimen oportunas, según reza el art. 929 del C. de C. (sentencia del TS de 6.06.1977 y sentencia de la AT de Barcelona de 30.06.1987), que deberá resolverse con arreglo a lo dispuesto en la Sección Octava, que se refiere a las suspensiones de pagos y quiebras de las Compañías y empresas de ferrocarriles y demás obras públicas, y se completa con la Ley de 12 de noviembre de 1869, a la que remite el art. 1.320 de la 
LEC. Se interpreta, por tanto, que las sociedades mercantiles con responsabilidad limitada (SA y SRL), incluso declaradas en quiebra fraudulenta, pueden alcanzar un convenio con sus acreedores, para cuya calificación no será preciso oír a los síndicos, si no hubiesen sido nombrados, como declara la citada STS de 8.06.1880: «...Que también son infundados los motivos de casación en que se pretende el imposible de que en la pieza de calificación de una quiebra se oiga a síndicos que no existen, ni deben existir, puesto que realizado el convenio no había para qué proceder a su nombramiento, y bastaba la representación fiscal para el único interés restante de la causa pública».

En las sociedades de capital (sociedades anónimas y de responsabilidad limitada), que no se hallen en liquidación, puede acordarse en el convenio su continuidad o traspaso (art. 928 C. de C.). El profesor De la Oliva ${ }^{37}$ señala una aparente antinomia entre el art. 928 y el art. $221.3 .^{\circ} \mathrm{C}$. de C., en cuanto que, según éste, la quiebra determina la disolución de la sociedad, que algunos autores tratan de salvar con argumentos que le parecen poco convincentes, como el maestro Garrigues, sobre la distinción entre disolución y extinción de las sociedades, aunque en el fondo está de acuerdo con este autor, pero no en la presentación argumental. A su juicio el art. 221.3. es una regla general, más que nada de constatación de que la declaración judicial de quiebra inhabilita, y así no se puede seguir comerciando, mientras que el art. 928 supone un desenlace excepcional, rectificatorio del proceso de cuyo inicio da cuenta el art. 221.3. ${ }^{\circ}$. A mi entender, los arts. 260.2 del TRLSA y 104.2 de la LSRL, que simplemente facultan al órgano social para disolver con causa en la declaración de quiebra, han dejado sin efecto la aplicación para estas compañías del art. 221.3. ${ }^{\circ}$ del C. de C.

Parece que en los supuestos comentados sobre proposiciones de convenio concursal, en suspensiones de pagos o quiebras en tramitación, después del 1 de septiembre de 2004, deberán respetarse las disposiciones de los arts. 99 y 100, así como los arts. 103, 118 y 121 de la nueva Ley.

\section{Suspensión de pagos}

Puede convenirse que en el procedimiento de suspensión de pagos los plazos establecidos por la Ley especial habrán de contarse por días hábiles, y, cuando señala meses, deberá prescindirse del mes de agosto,

37 Oliva, Andrés de la y Fernández, Miguel Angel, Derecho procesal civil, Madrid, Centro de Estudios Ramón Areces, 1991, vol. IV, pág. 412. 
aunque el art. 305 de la LEC menciona que los términos señalados por meses se contarán por meses naturales. En la suspensión de pagos un plazo establecido por meses se encuentra en el último párrafo del art. 18 para la tramitación escrita del convenio. Si se concediese un plazo de cuatro meses para la presentación al juzgado de la proposición de convenio con la adhesión de los acreedores, y entre ellos se comprendiese agosto, estimo que deberá descontarse como inhábil.

En materia de plazos debe destacarse el art. 24 de la LSP: «Los plazos establecidos en esta Ley se entenderán vencidos por su mero transcurso, sin necesidad de apremio, incluso en el juicio de calificación a que alude el artículo 20». La literalidad de este precepto, se pone en relación con el art. 134 de la LEC, cuyo primer párrafo señala que los plazos establecidos son improrrogables. En el procedimiento de suspensión de pagos, cuando se trata de plazos improrrogables la propia Ley se encarga de explicitarlo, así en los arts. 2, 8, 10, 17, 18 y 19, además de los mencionados de caducidad, que una vez transcurridos producen la preclusión y se pierde la oportunidad de realizar el acto de que se trate (art. 136 LEC).

El primer párrafo del art. 10 de la LSP establece: «... En los casos de insolvencia definitiva no se acordará la convocatoria [de la junta de acreedores] hasta que transcurra el plazo de quince días, señalado en el artículo 8, para la consignación o afianzamiento del déficit. Si el juez, cumplido este trámite, mantuviese la calificación de insolvencia definitiva, convocará inmediatamente la junta, a no ser que en el plazo de cinco días el suspenso o acreedores que representen los dos quintos del total pasivo soliciten que se sobresea el expediente o que se declare la quiebra». Plazo de caducidad, dentro del cual podrá solicitarse la declaración de quiebra, voluntaria o necesaria, que dará lugar a la denominada quiebra consecutiva.

Los demás plazos señalados en la Ley especial, considero que pueden ser ampliados por decisión judicial, y destaco, por su especial relevancia: a) El de quince días del art. 8, dada la dificultad de consignar o afianzar en plazo tan breve; b) El de treinta días del art. 19, dada la transcendencia de que se puedan lograr adhesiones suficientes durante este segundo plazo, siempre que se acredite ante el juzgado la necesidad de su ampliación, si concurriesen circunstancias extraordinarias; c) El término no inferior a veinte días ni mayor de sesenta, que el art. 8 establece para que los interventores redacten el dictamen, puede ser insuficiente para cumplir responsablemente con el mandato legal, dada la dimensión actual de algunas empresas y la complejidad de sus operaciones.

La realidad empresarial del tiempo en que ha de ser aplicado este precepto redactado en 1922, al amparo del art. 3.1 del C. Civil, permite 
al juzgado ampliar el corto plazo estipulado, sin necesidad de acudir a fórmulas complejas, como la que se plantea cuando los interventores, a punto de vencer el plazo señalado en la providencia de admisión de la solicitud de suspensión de pagos, y teniendo pendiente de verificar determinados particulares de los extremos objeto de informe, presentan su dictamen con la mención expresa a su contenido parcial o incompleto, a veces, huérfano de conclusiones, para que el juez, a su vista, adopte la resolución, para mejor proveer ${ }^{38}$, concediéndoles un nuevo plazo para que preparen el dictamen íntegro.

Sobre términos y plazos, resulta de interés el auto del Tribunal Superior de Justicia de Cataluña, de 22.09.94, que cita abundante jurisprudencia e incide en el carácter preclusivo de los plazos procesales en aras de garantizar la seguridad jurídica.

\section{Quiebra}

\section{Sección 1. a . Declaración de quiebra}

El art. 1.017 del primer C. de C. establece que es obligación de todo empresario, que se encuentre en estado de quiebra, ponerlo en conocimiento del juzgado de su domicilio, dentro de los tres días siguientes al que hubiere cesado en el pago corriente de sus obligaciones, haciendo una exposición en la que se manifieste en quiebra, designe su domicilio y todos los lugares de su establecimiento. Se pone en duda la vigencia de este precepto, según Rojo y otros ${ }^{39}$, particularmente en cuanto al indicado plazo de tres días, por el contenido del art. 871 del C. de C., que hace referencia al plazo de cuarenta y ocho horas para presentarse en suspensión de pagos, tácitamente derogado, dada la regulación de este procedimiento por Ley especial de 26.07.1922, según opinión mayoritaria de la doctrina mercantil: González de Echávarri y Miguel

38 «Providencia del Magistrado-Juez n. ${ }^{\circ}$ 4. Señor Martínez Llebres. Bilbao, nueve de diciembre de mil novecientos setenta y siete. Para mejor proveer y con suspensión, por quince meses, del plazo para dictar la resolución a que se refiere el párrafo $4 .^{\circ}$ del artículo 8 de la Ley de Suspensión de Pagos de 26 de julio de 1922, como antecedente necesario para determinar en dicho auto el alcance de la insolvencia provisional o definitiva de la suspensa, requiérase a los Sres. Interventores Judiciales para que en el plazo indicado, e improrrogable, emitan su dictamen en los términos prevenidos en los dos primeros párrafos del mencionado artículo octavo. Comuníquese esta resolución a los Sres. interventores y al suspenso».

39 Rojo Fernández-Río, Angel, Beltrán SÁnchez, Emilio M. y CAMPuZano LaguiLLo, Ana Belén, Legislación y jurisprudencia concursales. Pamplona, Aranzadi, 1997, págs. 407-408. 
Romero $^{40}$, Garrigues ${ }^{41}$ Torres de Cruells ${ }^{42}$, Sagrera Tizón ${ }^{43}$, Bisbal ${ }^{44}$, Mascarell $^{45}$, Menéndez ${ }^{46}$, Cordón Moreno ${ }^{47}$ y Rojo, Beltrán y Campuzano ${ }^{48}$.

Garrigues ${ }^{49}$ sostiene, con base en el art. 875 del C. de C. y la supresión del segundo párrafo del art. 871, por la Ley de 10.06.1897, que el comerciante no tiene la obligación de presentarse en estado de quiebra, sino que la quiebra se declara cuando la pide el deudor, pese al obstáculo del art. 889.2. ${ }^{\circ}$, que considera quebrados culpables a los que no hubieren hecho su manifestación de quiebra en el término y forma que se prescribe en el art. 871, tácitamente derogado.

El auto de la AP de La Rioja, de fecha 29.12.1997, considera que no existe obligación por parte del empresario, en estado de insolvencia, de pedir la declaración de quiebra de una manera obligatoria, y debe entenderse materialmente suprimido y derogado el art. 1.017 del primer C. de C., según declara en el Fundamento de Derecho Tercero. Puede llegarse a la conclusión de que el plazo mencionado no rige actualmente.

Respecto al cómputo del plazo para impugnar la declaración de quiebra necesaria, el art. 1.325 de la anterior LEC se remite al 1.028 del primer C. de C., que señala el derecho del deudor a pedir la reposición del auto declarativo dentro de los ocho días siguientes a su publicación. La STS de 12.02.1982 considera su cómputo a partir de que se publiquen los edictos acordados en el auto recurrido. La SAT de Burgos de

40 González de Echávarri y Vivanco, José M. a y Miguel Romero, Mauro, Comentarios a la Ley de Suspensión de Pagos. Valladolid, Emilio Zapatero (imp.), S. A., pág. 153.

41 Garrigues, Joaquín, Dictámenes de Derecho mercantil. Madrid, Aguirre (imp.), 1976, tomo II, págs. 312-314.

${ }^{42}$ Torres De Cruells, Joaquín, La suspensión de pagos. Barcelona, Bosch, 1957, pág. 83.

43 Sagrera Tizón, José M. ${ }^{\text {a }}$, Comentarios a la Ley de Suspensión de Pagos. 2. a ed., Barcelona, Bosch, 1989, Vol. I, págs. 164-166.

${ }_{4}$ BisBal MÉndeZ, Joaquín, La empresa en crisis y el Derecho de quiebras (Una aproximación económica y jurídica a los procedimientos de conservación de empresas). Bolonia, Publicaciones del Real Colegio de España (Studia Albornotiana IL), 1986, págs. 150-151.

${ }^{45}$ Mascarell Navarro, M. a José, Aspectos procesales de la Ley de Suspensión de Pagos. Granada, Comares, 1994, págs. 12-13.

46 MenÉndEZ, Aurelio, «Sobre la reforma del Derecho concursal y el apoyo de los estudios económicos», Revista del Consejo General de la Abogacía Española, núm. 2, septiembre 1994, págs. 6-7. «Breves reflexiones sobre la reforma del Derecho concursal», en Homenaje a José M. ${ }^{a}$ Chico y Ortiz. Coordinador: Juan Luis Gimeno. Madrid, Colegio de Registradores de la Propiedad y Mercantiles de España/Marcial Pons, 1995, págs. 1316-1317.

47 Cordón Moreno, Faustino, Suspensión de pagos y quiebra. Una visión jurisprudencial. Pamplona, Aranzadi, 1995, págs. 196-197.

48 Rojo Fernández-Río, Angel, Beltrán SÁnchez, Emilio M. y Campuzano LaguiLLO, Ana Belén, op. cit., pág. 109.

49 Garrigues, Joaquín, op. cit., tomo II, págs. 312-314. 
2.12.1986, ante la posibilidad de multiplicidad de dies a quo, se decanta por la aplicación del art. $303^{50}$ de la LEC y señala el día de la notificación. En la práctica forense, cuando los edictos se publican en distintos medios, se toma en consideración la fecha de aquél en que ha tenido lugar la última publicación. De la Oliva ${ }^{51}$ entiende que en los casos en que la declaración de quiebra se efectúe mediante edictos que se publiquen en distintos lugares y fechas, debería adoptarse como dies a quo, a efectos del cómputo del plazo de ocho días que establece el art. 1.028 del viejo C. de C., el día de la última publicación. Torres de Cruells $^{52}$ era de la misma opinión. Según la SAP de Asturias, de fecha 13.07.2000, cuando el Juzgado tiene por personado al quebrado, éste toma conocimiento de todo lo actuado, incluido el auto declaratorio de quiebra, sin que pueda en este caso computarse como día de inicio del plazo la fecha de su publicación en el Boletín Oficial, cómputo éste que sólo se aplica en el caso de que la declaración de quiebra se produzca sin la manifestación espontánea del quebrado o sin intervención alguna por su parte en el expediente, y así se declara en el Fundamento de Derecho Primero.

En la quiebra voluntaria, el plazo para oponerse a su declaración, por parte de los acreedores y terceros interesados, puede computarse de igual modo, aunque será de tres días, de ser aplicable el art. 1.170 de la LEC, por remisión del art. 1.319 de la propia Ley. Así se deduce de la SAP de Barcelona, de fecha 19.10.1995, referida a la declaración de quiebra voluntaria, que en su Fundamento de Derecho Primero declara: "Es lo cierto que el "dies a quo" del plazo de tres días, para formular oposición a la quiebra, no es aquél en que el opositor tuvo conocimiento más o menos exacto de su declaración, sino, conforme al citado artículo 1.171 de la Ley Procesal Civil, el de la citación de aquél, personal o, en su defecto, edictal, para el juicio de quiebra; en el caso presente no medió citación personal a los acreedores de la quebrada, sino por edicto, publicado en el Boletín Oficial de la Provincia el día 26 de abril de 1994, de modo que la demanda de oposición, interpuesta

50 Art. 133.1 de la nueva LEC: «Cómputo de los plazos. 1. Los plazos comenzarán a correr desde el día siguiente a aquél en que se hubiere efectuado el acto de comunicación del que la Ley haga depender el inicio del plazo, y se contará en ellos el día del vencimiento, que expirará a las veinticuatro horas. No obstante, cuando la Ley señale un plazo que comience a correr desde la finalización de otro, aquél se computará, sin necesidad de nueva notificación, desde el día siguiente al del vencimiento de éste...».

51 Oliva, Andrés de la y Fernández, Miguel Angel, Derecho procesal civil. Madrid, Centro de Estudios Ramón Areces, 1991, Vol. IV, pág. 385.

52 TorRes De CRUELLS, Joaquín, «La reposición de la declaración de quiebra», Revista de Derecho Procesal, 1957, págs. 950-952. 
el siguiente día 29 del mismo mes, lo fue temporáneamente, y, por tanto, el motivo debe desestimarse».

Sobre oposición al auto de declaración de quiebra, el magistrado Manresa $^{53}$ analiza los arts. 1.170 y 1.171 de la anterior LEC y señala: «... en la ley anterior... si bien no se desconoció nunca el derecho que tiene cualquier acreedor legítimo para oponerse a la declaración de concurso, ya sea voluntario o necesario, cuando haya sido dictada sin su intervención y le cause perjuicio, no era uniforme la práctica sobre el término y procedimiento para hacer uso de ese derecho. A fin de evitar esta irregularidad se adicionaron dichos dos artículos, declarando el derecho y las causas en que puede fundarse, y el tiempo y modo de utilizarlo.

Todo acreedor legítimo - debiendo entenderse por tal el que tenga a su favor un título de crédito con fuerza ejecutiva o un mandamiento de ejecución, como se declara en el art. 1.159 y hemos expuesto en su comentario - tiene el derecho de oponerse a la declaración de concurso, ya sea voluntario o necesario, lo cual habrá de entenderse en el caso de que no haya sido hecha a su instancia dicha declaración, ni haya sido parte en la oposición formulada por el deudor (art. 1.166) ...»

La oposición a la declaración de concurso, en los casos de que se trata, ha de deducirse dentro de los tres días siguientes al de la citación del deudor, cuando ésta le haya sido hecha personalmente por ser conocido su domicilio, conforme al art. 1.198, y en otro caso, dentro del término de los edictos, que, según los artículos 1.193 a 1.197, deben publicarse citando a los acreedores para que comparezcan en el juicio con los títulos de sus créditos...

Esos términos son improrrogables, puesto que, transcurridos, no puede admitirse la oposición, según prevención expresa de la ley. Del verbo «deducir» empleado en el art. 1.171, y del procedimiento que en el mismo artículo se establece, se infiere que el término de los tres días, o de los edictos, no es sólo para anunciar la oposición, sino también para formalizarla, alegando los hechos y los fundamentos de derecho en que se apoye. De este escrito y de los documentos que se acompañen, deberán presentarse tantas copias cuantas sean las partes personadas en el juicio del concurso. Por medio de otrosí se pedirá la formación de la pieza separada para sustanciar este incidente, designando los particulares que haya de contener, conforme a lo prevenido en el art. $747^{54}$, y en su caso, que se reciba a prueba (art. $750^{54}$ ).

53 Manresa y Navarro, José María, Comentarios a la Ley de Enjuiciamiento Civil, Madrid, Imprenta de la Revista de Legislación, 1891, tomo V, págs. 69-71.

54 Arts. 392 y 393 de la nueva LEC: «Art. 392. Planteamiento de las cuestiones incidentales. Inadmisión de las que no sean tales. 1. Las cuestiones incidentales se plantearán 
El comisario y el depositario son cargos de aceptación voluntaria y, por tanto, renunciables. Estimo que resulta aplicable el procedimiento y las causas de recusación que se establecen, para los peritos, en los arts. 124 a 128 y 343 de la vigente LEC. La impugnación y remoción del comisario y depositario puede producirse por las mismas causas y siguiendo idéntica tramitación que para los síndicos, por aplicación extensiva de los arts. 1.348 y 1.349 de la anterior LEC. El plazo para impugnar dichos nombramientos será el general de cinco días, establecido en el art. 452 de la vigente LEC para el recurso de reposición.

Declarada la quiebra necesaria, a solicitud de acreedores, el quebrado será requerido para la presentación del balance general, en el término de diez días (art. 1.060 C. de C. viejo), referido a la fecha del auto de declaración de quiebra, y si no lo hiciera será nombrado por el juez un experto para que lo formule en un plazo no superior a quince días (art. 1.061 C. de C.).

El plazo para la presentación al juzgado, por el comisario, del estado de los acreedores del quebrado, según señala el art. 1.063 y ratifica el art. 1.342 de la citada Ley procesal, es de tres días, a partir de la declaración de quiebra, declaración que se hace por auto, que debe incluir el nombramiento de comisario de la misma, como ordena el art. 1.333 de la misma LEC, además de contener otras disposiciones comprendidas en el art. 1.044 del C. de C. antiguo. Consecuentemente, prima facie, podría afirmarse que el mencionado plazo de tres días comienza

por escrito, al que se acompañarán los documentos pertinentes y en el que se propondrá la prueba que fuese necesaria y se indicará si, a juicio de quien proponga la cuestión, ha de suspenderse o no el curso normal de las actuaciones hasta la resolución de aquélla. 2. El tribunal repelerá, mediante auto, el planteamiento de toda cuestión que no se halle en ninguno de los casos anteriores». "Art. 393. Admisión, sustanciación y decisión de las cuestiones incidentales. 1. En el procedimiento ordinario no se admitirá el planteamiento de ninguna cuestión incidental una vez iniciado el juicio, y en el verbal, una vez admitida la prueba propuesta. 2. En la providencia sucintamente motivada en que se admita el planteamiento de la cuestión se resolverá si ha de considerarse de previo o de especial pronunciamiento, suspendiéndose, en el primer caso, el curso ordinario de las actuaciones. 3. Trasladado a las demás partes el escrito en que se plantee la cuestión, podrán contestar lo que estimen oportuno en el plazo de cinco días y, transcurrido este plazo, el tribunal citará a las partes a una comparecencia, que se celebrará conforme a lo dispuesto para las vistas de los juicios verbales. 4. Formuladas las alegaciones y practicada, en su caso, la prueba que en la misma vista se admita, si la cuestión fuere de previo pronunciamiento, se dictará, en el plazo de diez días, auto resolviendo la cuestión y disponiendo lo que sea procedente respecto a la continuación del proceso. Si la cuestión fuere de especial pronunciamiento, será resuelta, con la debida separación, en la sentencia definitiva. 5. Cuando la cuestión se resuelva por medio de auto, si éste acordare poner fin al proceso, cabrá recurso de apelación, y si decidiere su continuación, no cabrá recurso alguno, sin perjuicio de que la parte perjudicada pueda impugnar la resolución al apelar la sentencia definitiva». 
a contar a partir de la aceptación del cargo por el comisario, siempre que obre en autos el balance general de los negocios del quebrado, circunstancia que sólo podrá darse en las quiebras voluntarias.

Si la quiebra fuese necesaria, para el cómputo del repetido plazo de tres días, habrá de esperarse a que se practique la diligencia de ocupación de bienes y papeles de comercio del quebrado, que ordena el art. 1.350 de la anterior LEC, en la forma señalada en el art. 1.046 del primer C. de C., al que se remite, habida cuenta que será a partir de la ocupación cuando podrá el comisario acceder al balance y, en su caso, al libro mayor o demás libros y papeles del quebrado.

En resumen, considero que el plazo de tres días, establecido para que el comisario forme y presente al juzgado el estado de los acreedores del quebrado, será computable a partir de: a) La fecha de aceptación del cargo de comisario, en la quiebra voluntaria; b) La fecha de la diligencia de ocupación de los bienes y papeles de comercio del quebrado, en la quiebra necesaria.

\section{Sección 2. . Administración de la quiebra}

El comisario de la quiebra dicta las providencias interinas que sean urgentes para la seguridad y buena conservación de los bienes de la masa, sin perjuicio de lo que, en definitiva, resuelva el juzgado (art. 1.045.2. ${ }^{\circ} \mathrm{ci}$ tado y art. 1.363 de la anterior LEC). Rives y Martí55 señala que los acreedores y los síndicos están facultados para pedir la reforma de esas providencias al juez de primera instancia que, a la vista de la reclamación y del informe del comisario sobre ella, resolverá de plano. La anterior Ley no establece el término dentro del cual ha de solicitarse la reforma, por lo que se aplicará por analogía la regla general de los tres días que señala el artículo 452 de la vigente LEC.

El depositario presentará la rendición de cuentas al juzgado, que deberá ser informada por el comisario y la sindicatura (art. 1.356 de la anterior LEC, que se remite al juicio de concurso - art. 1.185- y art. 1.082 del viejo C. de C.). Manresa ${ }^{56}$, refiriéndose al concurso, señala que el depositario, como todo el que administra bienes ajenos, debe rendir cuenta de su administración en el término de quince días, desde su cese, ante el juzgado que lo nombró, dándose audiencia a los síndicos por el término que el juez estime necesario.

55 RIVES Y MARTí, Francisco de P., Teoría y práctica de actuaciones judiciales en materia de concurso de acreedores y quiebras, con sus preliminares quita y espera y suspensión de pagos, 3. ${ }^{\mathrm{a}}$ ed., Madrid, Instituto Editorial Reus, 1954, tomo II, págs. 479-480.

56 Manresa y Navarro, José María, op. cit., tomo V, pág. 86. 
La impugnación de las cuentas del depositario, que cita el referido art. 1.356 y se remite al orden establecido en el juicio de concurso (art. 1.185 de la anterior LEC), contempla la audiencia de la sindicatura, sustanciándose por los trámites de los incidentes, en ramo separado de la pieza de administración, establecido para los abintestatos en los arts. 1.013 a $1.015^{57}$ de la misma Ley.

El nombramiento de síndicos podrá ser impugnado ante el juez (art. 1.347 de la anterior LEC), por el deudor y por cualquiera de los acreedores personados que no hubieren asistido a la junta, o que hubieren disentido de la mayoría y protestado en el acto contra la elección, y el plazo para presentar dicha impugnación es de tres días, según el art. 1.220 de la anterior LEC, computados de la siguiente forma: a) Desde la fecha de celebración de la junta, para el deudor o el acreedor que la deduzca, si hubieren asistido a ella y hecho constar su protesta; b) Desde la publicación del nombramiento de síndicos, en otro caso. Así se declara en la vieja STS de 28.01.1874: "Una vez hecho en junta general de acreedores el nombramiento de los síndicos de las quiebras, sólo puede ser impugnado por tacha legal que obste a la persona nombrada para ejercer este encargo, o por haber procedido contra derecho en el modo de su elección; siendo necesario para que pueda admitirse esta reclamación que la haya precedido la protesta del reclamante contra el nombramiento ante la junta de acreedores en el acto de publicarse éste, y que se deduzca ante el Tribunal dentro de los tres días siguientes, por cuyo transcurso queda sin efecto la protesta con arreglo a lo dispuesto en el art. 194 de la Ley de Enjuiciamiento Mercantil».

No se señala plazo para que los síndicos procedan a la formación del inventario de los bienes, efectos, libros, documentos y papeles de la quiebra, por entrega del depositario (art. 1.185 LEC de 1881), suscribiendo la correspondiente diligencia (art. 1.355 LEC que se remite a los arts. 1.079 a 1.081 del C. de C. antiguo), y que autorizará con su

57 Art. 800 de la nueva LEC: «Rendición final de cuentas. Impugnación de las cuentas. 1. Cuando el administrador cese en el desempeño de su cargo, rendirá una cuenta final complementaria de las ya presentadas. 2. Todas las cuentas del administrador, incluso la final, serán puestas de manifiesto a las partes en la Secretaría, cuando cese en el desempeño de su cargo, por un término común, que el tribunal señalará mediante providencia según la importancia de aquéllas. 3. Pasado dicho término sin hacerse oposición a las cuentas, el tribunal dictará auto aprobándolas y declarando exento de responsabilidad al administrador. En el mismo auto, el tribunal mandará devolver al administrador la caución que hubiere prestado. 4. Si las cuentas fueren impugnadas en tiempo hábil, se dará traslado del escrito de impugnación al cuentadante para que conteste conforme a lo previsto por los artículos 404 y siguientes, continuando la tramitación con arreglo a lo dispuesto para el juicio verbal». 
asistencia el comisario, de la que dará fe el secretario judicial. Habrá de estarse, por tanto, a lo que señale el juzgado.

Los síndicos presentarán los estados mensuales de la administración de la quiebra al comisario, quien los pasará con su informe al tribunal (art. 1.095 del C. de C. viejo). Al respecto, Rives y Martí58 y Garrigues ${ }^{59}$ explican que, en virtud del artículo 1.095 del antiguo C. de C., los síndicos presentarán mensualmente un estado de la administración de la quiebra al comisario, y éste lo presentará al juzgado con su informe. Todo acreedor podrá tener a sus expensas copia de estos estados, si así lo solicita, y exponer lo que estime procedente a los intereses de la masa. Estas reclamaciones se dirigirán al juzgado en forma de exposiciones, dándose traslado al comisario para que informe, con lo que el juez dictará las providencias que estime necesarias en interés de la masa. En parecidos términos se pronuncia el art. 1.362 de la LEC de 1881, matizando el art. 1.232 de la misma LEC, para el concurso, que con los estados o cuentas de administración se formará un ramo separado de la pieza primera (segunda de la quiebra), a disposición de los acreedores y del deudor, que quieran examinarla.

No se establecen plazos, en la anterior LEC ni en el primer C. de C., para la presentación de dichos estados de administración, por la sindicatura al comisario, por lo que habrá de estarse a lo que el juzgado acuerde.

\section{Sección 3. . Efectos de la retroacción de la quiebra}

En cuanto al momento procesal oportuno (temporaneidad) para decidir ex officio la revisión de la fecha de retroacción o para su solicitud por las partes legitimadas, Cordón Moreno ${ }^{60}$, que cita a Carreras, acepta que la fecha provisional se convierta en definitiva, es decir, se pronuncia dando por finalizada tal posibilidad de revisión, al término del proceso de examen y reconocimiento de créditos. Este momento se identifica con la primera fase de la junta de graduación de créditos o con la tramitación de la pieza cuarta, cuando ganan firmeza las resoluciones dictadas en los correspondientes ramos separados sobre créditos pendientes de reconocimiento. La jurisprudencia, en opinión de Ramírez ${ }^{61}$, aborda esta cuestión de forma poco clara y aun contradictoria.

\footnotetext{
58 Rives y Martí, Francisco de P., op. cit., tomo II, pág. 478.

59 Garrigues, Joaquín, op. cit., tomo II, pág. 97.

60 Enciclopedia JuRídica BÁsicA, Alfredo Montoya Melgar (dir.). Madrid, Civitas, 1995, Vol. IV, págs. 5441-5442.

61 RAmírez, José A., op. cit., tomo II, pág. 386.
} 
Habida cuenta de la información que puede proporcionar el reconocimiento de créditos, sobre las operaciones que dieron lugar a su nacimiento, me inclino por la caducidad de acciones, para solicitar la determinación de la fecha definitiva de retroacción, cuando hayan adquirido firmeza los acuerdos sobre reconocimiento de créditos en la junta de graduación, pues la retroacción de los efectos de la quiebra (consecuentemente el señalamiento de la fecha) ha de tomar en consideración los actos que sean jurídicamente expresión directa de un sobreseimiento de sus obligaciones y, también, aquellos otros cuyas características pongan de manifiesto el estado patrimonial de insuficiencia que había de provocarla, revelada a través de concretos actos patrimoniales del deudor tendentes a burlar la par conditio creditorum.

Los síndicos deben formar, dentro del plazo de diez días inmediatos a la diligencia de inventario y entrega de bienes, los tres estados de retroacción previstos en los arts. 1.368 y 1.370 de la anterior LEC, para su entrega al comisario, a efectos de comprobación y visado, quien los presentará al juzgado con su informe, particularmente relativo a las reclamaciones y demandas que autorice entablar a la sindicatura. El contenido de tales estados se ordena en los mentados artículos, con remisión al primer C. de C. (arts. 1.038 a 1.041), pero deben entenderse sustituidos por los arts. 879 a 881 del vigente Código Mercantil.

\section{Sección 4.․ Examen, graduación y pago de los créditos contra la quebrada}

Una vez nombrados los síndicos, previa aceptación del cargo, y habiéndose comunicado dicho nombramiento a los acreedores mediante circular por el comisario ( $\mathrm{sic}$ ) y publicados los correspondientes edictos (arts. 1.071 y 1.072 del C. de C. viejo y 1.217 de la anterior LEC), el juez dictará providencia para la convocatoria a la junta de acreedores de examen y reconocimiento de créditos, señalando la fecha de su celebración, que será el duodécimo día después de vencido el plazo prefijado para la presentación de documentos, y el término dentro del cual los acreedores hayan de presentar a los síndicos los títulos justificativos de sus créditos.

Procesalmente la obligada graduación de créditos debe prepararse por la sindicatura en dos secciones (estados de graduación), según el art. 912 del C. de C., cuyo orden se establece en los artículos 913 y 914, y acompañarán su dictamen respecto a cada crédito (art. 1.271 de la LEC), para su entrega al comisario, quien la examinará antes de su presentación al juzgado, con el informe correspondiente (art. 1.123 del C. de C. anti- 
guo). Este trámite se explica por el profesor González Huebra ${ }^{62}$, y se hacen eco Nogués y Martorell ${ }^{63}$ y el citado Soto Vázquez ${ }^{64}$, señalando que el comisario, a quien tienen que pasar (los síndicos) estos trabajos (estados de graduación), los examinará, verá si están conformes con lo acordado por la junta de reconocimiento, y los presentará al Tribunal.

Sobre plazos para la convocatoria de esta junta, considero derogado el art. 1.126 del antiguo C. de C. y de aplicación el art. 1.267 de la anterior LEC. Pero los citados Códigos guardan silencio sobre el plazo de entrega por la sindicatura al comisario de los estados de graduación y correspondientes dictámenes, así como del plazo de su presentación al juzgado por el comisario.

Podrán el deudor y determinados acreedores reclamar sobre la validez formal de la convocatoria, celebración y votaciones de la junta de acreedores para examen y reconocimiento de créditos, cuya demanda deberá deducirse dentro de los tres días siguientes al de la celebración de dicha junta (art. 1.265 de la anterior LEC), según declara la SAP de Sevilla, de 9.10.1997, en el Fundamento de Derecho Primero.

Celebrada la junta de graduación de créditos, en el plazo de treinta días, podrán ser impugnados los acuerdos de la junta sobre reconocimiento de créditos (art. 1.380 de la LEC de 1881) y las demandas de los acreedores se acomodarán al procedimiento establecido en el juicio de concurso (art. 1.381 de la misma LEC), que dedica a estas demandas los arts. 1.261 a 1.264 , con la salvedad de que el plazo de ocho días del art. 1.261 se amplía a treinta días (tomado del art. 1.107 del C. de C. antiguo), según Manresa ${ }^{65}$.

Los acuerdos de la junta de graduación de créditos o las resoluciones del juez podrán ser impugnados por los interesados a quienes pare perjuicio, según el art. 1.381 de la anterior LEC, que se remite, en cuanto a procedimiento impugnatorio, a las normas dispuestas para el juicio de concurso, es decir: a) Art. 1.261, en cuanto al reconocimiento de créditos, con la salvedad de que el plazo de ocho días se amplía a treinta días (tomado del art. 1.107 del C. de C. antiguo); b) Art. 1.265 en lo que puede afectar a la validez formal de la convocatoria, celebración y votaciones, cuya reclamación deberá deducirse dentro de los tres

62 González Huebra, Pablo, Tratado de quiebras. Madrid, Imprenta de C. González, 1856, pág. 166.

63 Nogués, Emilio José M. ${ }^{a}$ y Martorell y Rovira de CASellas, Luis, Quiebras y suspensiones de pagos. Comentarios al Libro IV del Código de Comercio. Madrid, La Propaganda Universal, 1897, segunda parte, pág. 590.

64 Soto VÁzQuEz, Rodolfo, Aspectos concursales del patrimonio del insolvente. Quiebras y concurso de acreedores, 2. a ed., Granada, Comares, 1998, págs. 435-436.

${ }^{65}$ Manresa y Navarro, José María, op. cit., tomo V, pág. 366. 
días siguientes a la celebración de la junta; c) Art. 1.275, respecto de los acuerdos adoptados en orden a la graduación de créditos, cuya demanda debe formularse dentro del término de ocho días, computables desde el día siguiente al de la celebración de la junta, para los acreedores concursales que hubiesen disentido del voto de la mayoría y reservado su derecho para impugnarlo; y, d) art. 1.276, que exige se sustancien por el trámite de los incidentes todas las impugnaciones que se hagan de los acuerdos de la junta o decisiones del juez sobre la graduación de créditos.

\section{Sección 5. . Calificación de la quiebra y rehabilitación del quebrado}

Para la calificación de la quiebra resulta preceptivo el informe del comisario, con el que se inicia la tramitación de la pieza quinta, abierta con testimonio del auto de declaración de quiebra, según ordena el citado art. 1.382 de la anterior LEC, y que deberá versar sobre los capítulos previstos en el art. 1.138 del viejo C. de C. El referido art. 1.382 no señala plazo para la presentación de este informe, limitándose a establecer que la pieza quinta empezará con dicho informe, por lo que considero que el comisario deberá atenerse al que se establezca en la resolución que ordene la apertura de la misma o a la que le emplace y requiera al efecto.

Es práctica habitual que se tramite la pieza de calificación como un expediente, en el que los síndicos presentan su exposición y deducen la pretensión formal sobre la clase de quiebra (fortuita, culpable o fraudulenta), sin plantear la pretendida calificación con los requisitos exigidos para los incidentes en la Ley de Enjuiciamiento Civil. Al margen de posibles polémicas doctrinales sobre el procedimiento concreto, me inclino a favor de que la sindicatura sea representada en esta demanda incidental por procurador y asistida de letrado, desde su iniciación, pues de otra forma los síndicos, por definición acreedores o en su representación, cuando no son letrados (es frecuente que actúen auditores de cuentas, economistas o titulares mercantiles), se encontrarán huérfanos de la imprescindible formación jurídica que se requiere para su defensa. Además, si no se iniciara como demanda incidental, cuando se abriese dicho proceso, en el supuesto de oposición, los acreedores con derecho a perseguir al fallido, que se hubiesen personado en el expediente, según el art. 895 del C. de C., podrían quedar privados del derecho de solicitar se reciba a prueba el incidente, si lo estiman necesario. $\mathrm{Al}$ respecto, Soto Vázquez ${ }^{66}$ reconoce que ningún precepto impone que

66 Soto VÁzquez, Rodolfo, Quiebras y concurso de acreedores. Las situaciones de insolvencia y la responsabilidad penal del deudor, Granada, Comares, 1994, pág. 250. 
esas pretensiones adopten la forma de una demanda civil, revestida de los requisitos del art. $524^{67}$ de la Ley de Enjuiciamiento Civil, pero tampoco existe inconveniente legal alguno en que adopten la forma de demanda, e incluso puede ser conveniente hacerlo así, si se tiene en cuenta que esa razonada exposición puede ser contestada por el deudor, oponiéndose a la misma si fuere contraria a sus intereses, y siguiéndose entonces el juicio por los trámites de los incidentes, sin nuevo traslado a los síndicos para alegaciones. Y concluye que una exposición que adopte la forma de demanda se ajustará más fácilmente a un orden de proceder de esta clase. En todo caso, el escrito de la sindicatura sobre calificación de la quiebra debe presentarse dentro de los quince días siguientes a su nombramiento (art. 1.383 LEC de 1881), una vez hayan recibido el traslado del informe del comisario,

\section{Sección $6 .^{\mathrm{a}}$ Del convenio entre los acreedores y el quebrado}

El plazo de ocho días, para la acción impugnatoria del convenio (art. 1.396 LEC de 1881 y 1.159 C. de C. de 1829), establecido en el art. 902 del C. de C., es de carácter procesal, según la generalidad de la doctrina (Ramírez ${ }^{68}$ y Sala Reixachs ${ }^{69}$ ), por lo que se computan únicamente los días hábiles. Este plazo empezará a contar el día siguiente de

67 Art. 399 de la nueva LEC: «La demanda y su contenido. 1. El juicio principiará por demanda, en la que, consignados de conformidad con la que se establece en el artículo 155 los datos y circunstancias de identificación del actor y del demandado y el domicilio o residencia en que pueden ser emplazados, se expondrán numerados y separados los hechos y los fundamentos de derecho y se fijará con claridad y precisión lo que se pida. 2. Junto a la designación del actor se hará mención del nombre y apellidos del procurador y del abogado, cuando intervengan. 3. Los hechos se narrarán de forma ordenada y clara con objeto de facilitar su admisión o negación por el demandado al contestar. Con igual orden y claridad se expresarán los documentos, medios e instrumentos que se aporten en relación con los hechos que fundamenten las pretensiones y, finalmente, se formularán valoraciones o razonamientos sobre éstos, si parecen convenientes para el derecho del litigante. 4. En los fundamentos de derecho, además de los que se refieran al asunto de fondo planteado, se incluirán, con la adecuada separación, las alegaciones que procedan sobre capacidad de las partes, representación de ellas o del procurador, jurisdicción, competencia y clase de juicio en que se deba sustanciar la demanda, así como sobre cualesquiera otros hechos de los que pueda depender la validez del juicio y la procedencia de una sentencia sobre el fondo. 5. En la petición, cuando sean varios los pronunciamientos judiciales que se pretendan, se expresarán con la debida separación. Las peticiones formuladas subsidiariamente, para el caso de que las principales fuesen desestimadas, se harán constar por su orden y separadamente».

68 Ramírez, José A., op. cit., tomo III, pág. 202.

69 Sala Reixachs, Alberto, «Las causas de impugnación al convenio», en Derecho Concursal II. (Cuadernos de Derecho Judicial). Madrid, Consejo General del Poder Judicial, 1996, págs. 243-244. 
la celebración de la junta. Ramírez ${ }^{70}$ concreta que, votado favorablemente un convenio, no obliga automáticamente a los acreedores, pues es preciso, para que tal obligatoriedad surja, la aprobación judicial, o sea, su homologación, y tal aprobación judicial no se produce automáticamente, sino después de transcurrido cierto plazo que la ley concede a los acreedores para que puedan oponerse a su aprobación por el juez. La oposición a la aprobación del convenio acordado en la junta se previene en el art. 902 del Código de Comercio. Se tramita, como incidente, con arreglo a lo dispuesto en los arts. 1.394 y 1.395 de la LEC de 1991, siendo legitimados los acreedores disidentes y los que no hubiesen concurrido a la junta, estando vedado a los acreedores que por el acta de la junta resultaren haber asentido en ella al convenio (art. 1.393 LEC).

70 RamíreZ, José A., op. cit., tomo III, págs. 199-200. 